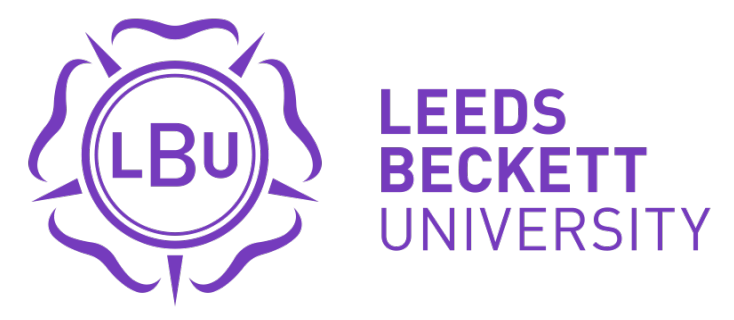

Citation:

Price, M and Surr, CA and Gough, B and Ashley, L (2020) Experiences and support needs of informal caregivers of people with multimorbidity: a scoping literature review. Psychology and Health, 35 (1). pp. 36-69. ISSN 1476-8321 DOI: https://doi.org/10.1080/08870446.2019.1626125

Link to Leeds Beckett Repository record:

https://eprints.leedsbeckett.ac.uk/id/eprint/5615/

Document Version:

Article (Accepted Version)

This is an Accepted Manuscript of an article published by Taylor \& Francis in Psychology and Health on 19 July 2019, available online: http://www.tandfonline.com/10.1080/08870446.2019.1626125

The aim of the Leeds Beckett Repository is to provide open access to our research, as required by funder policies and permitted by publishers and copyright law.

The Leeds Beckett repository holds a wide range of publications, each of which has been checked for copyright and the relevant embargo period has been applied by the Research Services team.

We operate on a standard take-down policy. If you are the author or publisher of an output and you would like it removed from the repository, please contact us and we will investigate on a case-by-case basis.

Each thesis in the repository has been cleared where necessary by the author for third party copyright. If you would like a thesis to be removed from the repository or believe there is an issue with copyright, please contact us on openaccess@leedsbeckett.ac.uk and we will investigate on a case-by-case basis. 
Experiences and support needs of informal caregivers of people with multimorbidity: a scoping literature review

Mollie L Price ${ }^{1 *}$, Claire A Surr ${ }^{2}$, Brendan Gough $^{3}$, Laura Ashley ${ }^{4}$

${ }^{1}$ School of Social Sciences, Leeds Beckett University, City Campus, Leeds, LS1 3HE, UK Email: m.price@ leedsbeckett.ac.uk; Tel: 01138128969

ORCID identifier: 0000-0002-7884-3644; Twitter: @ MolliePrice94

${ }^{2}$ School of Health and Community Studies, Leeds Beckett University, City Campus, Leeds, LS1 3HE, UK

Email: c.a.surr@leedsbeckett.ac.uk; Tel: 01138124316

ORCID identifier: 0000-0002-4312-6661; Twitter: @ clairesurr

${ }^{3}$ School of Social Sciences, Leeds Beckett University, City Campus, Leeds, LS1 3HE, UK Email: b.gough@leedsbeckett.ac.uk; Tel: 01138123934

ORCID identifier: 0000-0001-7438-0139; Twitter: @ BrendanGough7

${ }^{4}$ School of Social Sciences, Leeds Beckett University, City Campus, Leeds, LS1 3HE, UK Email: L.J.Ashley@leedsbeckett.ac.uk; Tel: 01138124980

ORCID identifier: 0000-0002-9439-3778; Twitter: @Dr_Laura_Ashley

*corresponding author 


\section{Experiences and support needs of informal caregivers of people with multimorbidity: a scoping literature review}

Objective: Describe and synthesise existing published research on the experiences and support needs of informal caregivers of people with multimorbidity.

Design: Scoping literature review. Primary database and secondary searches for qualitative and/or quantitative English-language research with an explicit focus on informal carers of people with multimorbidity (no date restrictions). Quality appraisal of included papers. Thematic analysis to identify key themes in the findings of included papers.

Results: Thirty-four papers (reporting on 27 studies) were eligible for inclusion, the majority of which were rated good quality, and almost half of which were published from 2015 onwards. The review highlights common difficulties for informal carers of people with multiple chronic illnesses, including practical challenges related to managing multiple health care teams, appointments, medications and side effects, and psychosocial challenges including high levels of psychological symptomatology and reduced social connectedness. Current gaps in the literature include very few studies of interventions which may help support this caregiver group.

Conclusion: Interest in this research area is burgeoning. Future work might fruitfully examine the potential benefits of audio-recorded health care consultations, and digitallydelivered psychosocial interventions such as online peer support forums, for supporting and enhancing the caring activities and wellbeing of this caregiver group.

Keywords: carers; caregivers; multimorbidity; comorbidity; psychosocial; unmet needs; experiences; interventions 


\section{Introduction}

The coexistence of two or more chronic conditions, where one is not necessarily more central than the other(s), is known as multimorbidity (Fortin, Soubhi, Hudon, Bayliss, \& van den Akker, 2007; Tinetti, Fried, \& Boyd., 2012). Multimorbidity is a growing public health concern, and an increasing challenge for health and social care providers and systems (Pefoyo et al., 2015). In England, approximately $25 \%$ of people aged over 60 are living with two or more chronic conditions (Department of Health, 2012), and owing to an ageing population, the proportion of people aged $65+$ with four or more chronic conditions is predicted to rise from $9.8 \%$ in 2015 to $17.0 \%$ in 2035 (Kingston, Robinson, Booth, Knapp \& Jagger, 2018). Multimorbidity is not just a concern for health and social care systems in England, but globally, with a high prevalence of multiple chronic conditions found in low, middle and high-income countries across Europe, Asia, Africa and North America (Garin et al., 2016). Multimorbidity is associated with increased dependency and complexity of care needs, higher health care utilisation and costs, and poorer quality of life and mortality outcomes (Bähler, Huber, Brüngger, \& Reich, 2015; Doessing \& Burau, 2015; Koller, Schön, Schäfer, Glaeske, van den Bussche \& Hansen, 2014; Lehnert et al., 2011; Marengoni et al., 2011). Most health care systems and services, as well as medical education and research, are currently configured within a single-disease framework, with specialist care having a siloed focus on individual conditions. Care for people with multimorbid conditions is therefore often fragmented, involving many different specialists and services, which can lead to logistical difficulties and excess consultation demands for both health care professionals and patients and families (Doessing \& Burau, 2015; Sinnott, Mc Hugh, Browne, \& Bradley, 2013). Multimorbidity is thus increasingly recognised as a significant public health concern and a growing challenge for health care providers and systems (Glynn et al., 2011; Moffat \& Mercer, 2015; Sinnott et al., 2013). 
Research has found that people with multimorbidity tend to have greater health care needs than those with one chronic illness, and face unique barriers to self-care, including challenges associated with multiple medications and the aggravation of one condition by the symptoms or treatment of another (Bayliss, Steiner, Fernald, Crane, \& Main, 2003; Duguay, Gallagher, \& Fortin, 2014; Liddy, Blazkho \& Mill, 2014). People living with multimorbidity are thus especially likely to rely on the support of informal caregivers. It is well-documented that unpaid informal caregiving is associated with high levels of stress hormones and selfreported stress, poorer immune function, increased levels of depressive and anxious symptoms, and cardiovascular morbidities (Allen et al., 2017; Aschbacher et al., 2008; Kim, Carver, Rocha-Lima \& Shaffer, 2013; Lavela \& Ather, 2010; Lovell \& Wetherell, 2011; Oken, Fonareva \& Wahbeh, 2011). Providing informal care for people with multiple chronic illnesses may be particularly burdensome, owing to their high use of health care services, high risk for adverse events and outcomes, and reduced ability to adhere to complex treatment regimens (Calderón-Larrañaga, Poblador-Plou, González-Rubio, Gimeno-Feliu, Abad-Díez \& Prados-Torres, 2012; Koroukian, Warner, Owusu \& Given, 2015; Lehnert et al., 2011; van Oostrom et al., 2014; Vogeli et al., 2007; Wong et al., 2014). Carers of people with multimorbidity may thus be particularly at risk of adverse consequences to their own health and wellbeing, and of struggling to cope with caregiving. Despite this, public health guidelines do not offer dedicated information or support strategies for this caregiver group. For example, recent UK guidelines on the management of multimorbidity do not acknowledge the key role, or consider the support needs, of informal carers of people with multimorbidity (National Institute for Health and Care Excellence, 2016).

Caregivers perform a vital role for the people they care for, but also perform an invaluable economic role in society, as it would be financially impossible for formal health and social care systems to provide the huge amount of unpaid care given by informal 
caregivers (Buckner \& Yeandle, 2015; Mittelman, 2005). It is important to understand the experiences and support needs of unpaid caregivers, in order to inform effective services and interventions to help support them in their caregiving role, and to help them maintain their own health and wellbeing. Although much qualitative and intervention research has been conducted with informal caregivers (e.g., Harding, List, Epiphaniou \& Jones, 2012; Røthing, Malterud, \& Frich, 2015; Thompson et al., 2007; van Ryn et al., 2011), and many studies have explored the experiences of patients with multimorbidity (e.g., Bayliss et al., 2003; Duguay et al., 2014; Signal et al., 2017), less research has focused specifically on informal caregivers of people with multimorbidity. Multimorbidity research is mainly patient-focused, and when informal carers are included, they often receive less attention, with findings focusing more on the patients' experiences and outcomes (e.g., Kuluski et al., 2013; Mason et al., 2016). Studies that have examined the experiences of caregivers of people with multimorbidity are diverse with regard to the range of combinations of physical and mental illnesses experienced by care-recipients. A synthesis of the research in this area will help to identify gaps and targets for future research, and to increase our understanding of the experiences and support needs that are common among caregivers of people with multimorbidity, irrespective of the care-recipients' specific health conditions. To our knowledge, no literature review has been published focusing on research with informal caregivers of people with multimorbidity.

This review aims to describe and synthesise existing published research on the experiences and support needs of informal caregivers of people with multimorbidity. We address three research questions:

1. What is the extent, range and nature of research looking at informal caregivers of people with multimorbidity? 
2. What is known about the experiences and support needs of informal caregivers of people with multimorbidity?

3. What are the research gaps in the existing literature on the experiences and support needs of informal caregivers of people with multimorbidity?

\section{Methods}

A scoping review method was employed, guided by the methodological framework set out by Arksey and O’Malley (2005) and later advanced upon by Levac, Colquhoun and O’Brien (2010). Scoping reviews enable the inclusion of quantitative, qualitative and mixed-methods studies, allowing for a more comprehensive understanding of the current state of knowledge. Although the review parameters are not limited to specific study types, scoping reviews are rigorous and methodical in their approach to examining the extent, range and nature of research activity in a particular area (Arksey \& O’Malley, 2005; Levac et al., 2010). Therefore, this method was considered the most appropriate to explore the status of the existing published literature.

\section{Inclusion and exclusion criteria and operational definitions}

Studies were included if they: (1) reported primary empirical research; (2) had an explicit focus on informal caregivers of people with multimorbidity; (3) were published (journal papers or doctoral theses); and (4) written in English. All study designs were eligible. No restrictions on the date of publication were employed (searches conducted October 2017).

Articles featuring accounts or outcomes of people with multimorbidity (and/or health professionals) as well as their informal caregivers were included, but in these cases only the results concerning the caregivers were extracted and analysed. As with other reviews of informal caregiver research (e.g., Deeken, Taylor, Mangan, Yabroff, \& Ingham, 2003), studies involving caregivers of children were excluded as the relationship of a parent caring 
for a child with a chronic condition is considered qualitatively different from other caregiver and care-recipient relationships, such as between spouses (Murphy, Christian, Caplin, \& Young, 2007; National Alliance for Caregiving, 2009).

Informal caregivers were defined as people who provide unpaid care for an individual (often a relative or friend) who cannot manage the basic activities of daily living due to disability and/or illness (Ashley, O’Connor, \& Jones, 2011). Multimorbidity was defined as the co-existence of two or more chronic conditions (physical, developmental and/or mental), where one is not necessarily more central than the other(s) (Fortin et al., 2007). In line with previous research (e.g., Hagger, Koch, Chatzisarantis, \& Orbell, 2017), physical and mental conditions were considered chronic if they were typical of lasting for three months or longer.

\section{Search terms, strategy and sources}

An extensive list of search terms was developed following discussions with an academic librarian and pilot searches, though as recommended by Arksey and O’Malley (2005), the search terms were updated following increasing familiarity with the literature. Examples of combinations of the search terms included: multimorbid* AND caregiver*; comorbid* AND carer*; 'multiple illnesses' AND carer*. Primary searches were conducted in seven electronic databases: PubMed, PsycINFO, PsychArticles, CINAHL, Scopus, Web of Science, and EThOS. The search field was set to 'Title/Abstract' or 'Abstract'. The full list of combinations of search terms used for all databases can be seen in Appendix 1 of Supplementary Material. Secondary searches were also undertaken, including searching the reference lists of the papers selected for inclusion in the review; searching research citing the final included papers using the 'cited by' functions on databases; and hand-searching key journals.

\section{Study screening and selection}


We employed a two-stage approach to study screening and selection in the primary database searches. In the first-stage, undertaken by MP, all study titles and abstracts were read to determine relevance against the inclusion criteria. If there was any uncertainty about the eligibility of a paper based on the title and abstract alone, it was brought forward for full-text screening (i.e., only papers which were unambiguously ineligible were rejected at this stage). In the second-stage, the full-text of all the papers brought forward was retrieved and read independently by both MP and LA to determine eligibility. Any papers for which eligibility was difficult to determine, or for which there were disagreements regarding eligibility, were re-reviewed and discussed between MP and LA until a consensus on inclusion was reached. It was pre-determined that if MP and LA could not reach a consensus on inclusion, a third coauthor's opinion would be sought.

\section{Quality appraisal}

The aim of scoping the literature is to be as comprehensive as possible, thus methodological quality is not used as an exclusion criterion in scoping reviews (Arksey \& O’Malley, 2005). However, a lack of quality assessment limits the uptake of scoping review findings into policy and practice (Grant \& Booth, 2009). Thus, the quality of included papers was assessed in this review using the Mixed Methods Appraisal Tool (MMAT - Version 2011; Pluye, Gagnon, Griffiths, \& Johnson-Lafleur, 2009; Pluye et al., 2011), a scoring system designed for use in systematic reviews that include qualitative, quantitative and mixed-methods primary studies. The MMAT comprises two screening questions and 19 quality criteria corresponding to five methodological domains: 1) Qualitative; 2) 'Randomised controlled'; 3) 'Non-randomised'; 4) 'Observational descriptive'; and 5) 'Mixed methods'. Each paper is appraised with the appropriate set/s of criteria for its design and methodology. Quality scores are calculated as percentages and presented using the following descriptors (from lower to higher quality): * = $25 \%, * *=50 \%, * * *=75 \%$ and $* * * *=100 \%$ (Pluye et al., 2011). Mixed-methods papers are 
appraised using the qualitative component, the appropriate quantitative component and the mixed-methods component, and the overall quality score is the lowest score of the three components. Two co-authors completed the quality appraisal independently and together reached a consensus on the quality rating for all included papers.

\section{Data extraction and synthesis}

Data synthesis involved two stages: (1) a descriptive summary of the extent, range, and nature of the reviewed research; and (2) a thematic analysis identifying key themes in the existing research findings concerning the experiences and support needs of informal caregivers of people with multimorbidity.

For the descriptive summary, study information was extracted and entered into a datacharting form by MP, which included: author(s), year of publication, the journal of publication, study location, study type (qualitative, quantitative or mixed-methods), sample (carer group; care-recipient group), objectives, design/methodology, analytic methods, outcome measures (if applicable), and main findings.

Thematic analysis was conducted to identify key themes in the existing literature concerning the experiences and support needs of informal caregivers of people with multimorbidity. Dixon-Woods, Agarwal, Jones, Young and Sutton (2005) highlight that using thematic analysis to synthesise both qualitative and quantitative research involves the identification of prominent or recurrent themes across the included literature, and summarising the findings of different studies under thematic headings. As recommended by Levac et al. (2010), guidance on conducting thematic analysis was sought for this stage from Braun and Clarke (2006). Included papers were first read repeatedly and initial notes made. A more formal coding process was then conducted and initial codes were generated for each individual study. Findings and quotes were only included in the coding process if they were 
related to the experiences and support needs of carers of people with multimorbidity. Thus, findings associated with patients and healthcare professionals were not extracted and coded. Once all the relevant findings from each paper were coded, codes were grouped together to determine patterns across the findings. As this was a review of existing findings, themes were derived inductively from the data and were not determined in advance.

\section{Results}

\section{Search outcome}

After removing duplicates, the primary database searches yielded 2674 papers. Following the title and abstract screening, 100 papers were brought forward for full-text screening. MP and LA completed the full-text screening independently and agreed on 90 papers (90\%), and discussed the remaining to reach a consensus on inclusion. There was no need for recourse to a third party. Thirty-four papers were eligible for inclusion, which reported on the findings from 27 different studies (i.e. some studies reported findings in multiple papers). See Figure 1 for a flow diagram of the search, screening and selection process. Table 1 summarises the characteristics of the included papers (references to which are made in square brackets, e.g., [7]).

\section{Quality appraisal}

The majority of the 34 included papers were rated $3 *$ or $4 *$ on the MMAT $(k=24,70.6 \%)$, eight papers were rated $2^{*}$, and two papers $1 *$ (see Table 1 ). The distribution of quantitative and qualitative papers was similar across the MMAT score categories (e.g., of the eight $4^{*}$ papers, 5 were quantitative and 3 qualitative).

Research Question 1: What is the extent, range and nature of research looking at informal caregivers of people with multimorbidity? 
Number and publication dates of studies included

We found 34 papers, reporting on 27 studies, with only $15(44.1 \%)$ of these focused exclusively on informal caregivers of people with multimorbidity; the remainder focused on both patients and caregivers $(k=12)$, or patients, caregivers and health care professionals $(k=7)$. Although no restrictions on the date of publication were employed in the searches, the majority of the included papers were published from 2010 onwards $(k=24,70.6 \%)$, with almost half published from 2015 onwards $(k=16,47.1 \%)$, demonstrating very recent burgeoning interest in this research area.

\section{Caregiver sample characteristics in the included studies}

As shown in Table 1, across the included studies, caregivers were recruited from nine countries, and sample sizes ranged from 5 to 1300 . The age of the caregivers ranged from 18 to 91 years (average age was reported in 12 of the 27 studies; $M=58.0$ years). Sixteen studies provided information on the gender of participants, with $71.8 \%(n=1354)$ of caregivers in these studies reported to be female. Of the studies $(k=18)$ that described the nature of the caregiver-care recipient relationships, people with multimorbidity were most commonly being cared for by their spouse (48.3\%) or adult child (37.8\%). The multimorbidities experienced by care-recipients in the included studies were diverse (see Table 1). Some studies focused on specific comorbid physical conditions, such as dementia and serious visual impairment [24,25], others on co-occurring mental and/or developmental disorders, including cooccurring mental illness and substance use disorder [1,4-6], and some studies did not focus on a specific combination of conditions, but instead included carers of people diagnosed with any two or more chronic conditions, though diagnoses commonly included diabetes, COPD, dementia, stroke, heart disease, arthritis, and liver and renal failure [10,11,15-23,29,32,34]. 
Of the 27 studies, 11 were quantitative, 14 were qualitative, and two were mixed-methods. As shown in Table 1, quantitative papers commonly reported cross-sectional questionnaire studies $[1,8,12-14,18,19,26,30]$, though three papers from two studies reported randomised intervention trials [20-22]. All qualitative studies (and qualitative elements of the mixedmethods studies) used interviews and/or focus groups.

\section{Research Question 2: What is known about the experiences and support needs of informal caregivers of people with multimorbidity?}

Five main themes were identified in the included papers' findings, concerning the experiences and support needs of caregivers: (1) Poor communication and coordination between different health care teams; (2) Multifaceted practical responsibilities and challenges of the caregiver

role; (3) Emotional and psychosocial burden of the caregiver role; (4) Lack of knowledge and information about care-recipients' medical diagnoses; (5) Difficulties accessing caregiver support and respite services. These themes and their sub-themes are summarised in Figure 2.

\section{Theme 1: Poor communication and coordination between different health care teams}

Poor communication and coordination between different health care teams was a widespread experience reported by many caregivers from diverse countries with different health care systems $[2,9,11,16,23-25,28,29,31-34]$. Carers described the challenges of receiving services from multiple providers that are single disease-focused [34], which include liaising with numerous professionals about care-recipients' different conditions [23] and being 'bounced' between services which are misaligned with care-recipients' individual needs [33]. Carers reported that communication of information between different professionals was poor, including test results, medications and medical histories, resulting in poor coordination, impersonal care, and conflicting information from different clinicians $[9,25,28,29]$. Specialist professionals were often unaware of comorbid diagnoses, and carers reported inadequate 
consideration by some services of the implications of other diagnoses on the management of existing conditions [2]. Lack of staff continuity was also commonly noted [23,32-34]. Carers expressed that their vital role was largely reflective of insufficient and uncoordinated professional services [33].

Carers proposed that coordination could be improved if clinicians dealt with carerecipients as a whole individual, taking into account their unique combination of conditions and how best to care for them holistically $[9,28]$. They suggested having a combined service for the multiple conditions and a designated professional coordinating all care-recipients' care [28]. Positive experiences carers had with professionals emphasised the importance of coordinating the different systems and having regular contact with consistent staff $[2,31,33]$, though it was noted that these tended to be about the behaviour of individual practitioners rather than system-based approaches [2]. Two studies highlighted the benefits of case managers in coordinating care for people with multimorbidity $[15,23]$. In one study caregivers reported that case managers fulfilled unmet needs by reducing their sense of being alone and helping increase their caregiving competencies and knowledge [23].

\section{Theme 2: Multifaceted practical responsibilities and challenges of the caregiver role}

Constant vigilance and increasing time demands. Multimorbidity caused increasing difficulties/complications for care-recipients and increased their dependency on the carer $[11,24,25,28,29,32]$. Caregiving was perceived as very demanding as it required constant vigilance of multiple chronic conditions and placed high and increasing demands on carers' time $[11,29,34]$. Caregiver time spent on care-recipient activities of daily living was found to be significantly higher for carers of people with two chronic conditions than carers of those with one [26]. Carers assisted with a wide range of tasks, including scheduling and attending medical appointments, providing physical care and stimulating and entertaining the care- 
recipient [2,17,18,25,34], and described having to 'do it all' [34, p.7]. One study found that carers who assisted with more health care tasks for the care-recipient, and who were younger, reported more difficulty providing assistance which was associated with greater caregiver strain and depression [18]. Quantitative studies reported that up to two-thirds of their carer sample were providing care every day [1,20]. Many carers reported having full responsibility for day-to-day care and being unable to leave their care-recipient for even brief periods of time $[25,28,31,33]$. The demands of their caregiver role meant some carers had to negotiate time off work [34], reduce their working hours to part-time or quit their jobs entirely [7,27], which for some led to financial strain.

Difficulty managing multiple medications and side effects. A task that carers commonly took responsibility for across the included studies was the management of care-recipients' medication regimens $[2,11,13,18,24,29,34]$. These regimens were typically complex, with care-recipients sometimes taking more than 10 different medications daily, and subject to frequent change [29,31,33-34]. Carers described 'constantly looking at medication' [34, p.7], and changes to medications as stressful [31], 'a complete mess' [33, p.5], abrupt, and a challenge as they brought new side effects [34]. Furthermore, changes to medications were reportedly carried out without input from carers and care-recipients [34]. Carers had the challenge of managing lack of adherence to medication and side effects due to disease complexity $[9,13,14,16,24,28]$, contributing to their subjective burden and stress $[13,14,16]$. Carers suggested that the capacity to manage medication could be improved through increased education and good communication with health care professionals [24].

Burden of coordinating different care services. Due to poor communication and coordination between different health care teams (previously reported, see theme 1), carers often assumed the burden of coordinating care for people with multimorbidity. Carers reported, for example, having to constantly re-inform professionals of care-recipients' multiple conditions at each 
appointment, and needing to keep their own medical records due to uncertainty that medical information will be disseminated between different care teams [9,23,29,32,34].

\section{Theme 3: Emotional and psychosocial burden of the caregiver role}

High levels of stress, anxiety, depression and emotional exhaustion. Carers experienced stress, anxiety and depression in relation to their caregiving role [1,10,11,14,17,27,30,33-34]. For example, Espie et al. [14] examined carers of people with comorbid epilepsy and intellectual disability, and found that one-third exhibited clinically significant anxiety symptoms, and around half had 'higher than usual stress' on the Caregiver Strain Index, with higher levels of stress found in younger caregivers. Qualitative studies found that carers reported feelings of sadness, anger, frustration, anxiety and depression [27,33,34]. Carers experienced recurrent anxiety in relation to care-recipient potential injuries and hospitalisations [27,31]; symptoms which they found distressing, such as seizures [31]; the uncertainty of what may happen to the care-recipient when they are not physically around [27,31]; and the uncertainty of the future [27]. Emotional exhaustion, fatigue and feeling worn out were also commonly reported by carers of people with multimorbidity [25,27,33,34]. Despite the psychological toll of caregiving, carers reported that professional services were directed to care-recipients' needs and not those of the carer, and that they felt 'abandoned' by the healthcare system [23, p.6].

Lack of time for self-care and leisure. Carers reported neglecting their own wellbeing as they were overwhelmed with the demands of caring for someone with multimorbidity. Carers described prioritising the needs of their care-recipient and having to put their own lives on hold, such that they had little time for self-care or leisure $[7,11,27,31,33]$, with some noting that they 'can't do anything' [31, p.136] and have 'no life' [11, p.7]. 
Detrimental impact on social relationships juxtaposed with a need for social contact.

Caregiving was commonly reported to have a negative impact on social relationships and connectedness. Carers reported that family care provision decreased their engagement in the community and led them to have fewer social relationships [33], and some carers reported having lost friends due to their lack of understanding of their complex and constrained circumstances $[11,28]$. Relationships with care-recipients could also be impacted, with some carers noting that they were often on the receiving end of care-recipients' frustrations and anger, which led to conflict between them and the care-recipient [27]. Williams et al. [11] highlighted differences in responses between spouses and adult children caregivers with regards to the impact of caregiving on relationships, with spouses reporting challenges related to loss of physical/sexual intimacy in their relationships, and adult children reporting conflicts with care-recipients due to past unresolved issues, and with siblings about caregiving tasks. Caregivers expressed a need for social contact to help them deal with the emotional impact of caregiving. Feeling socially connected helped carers meet the demands of caring for someone with multimorbidity, and carers praised opportunities for social interaction [11,25]. Some carers expressed the importance of sharing feelings of pain and/or happiness with other family members [7], though other carers felt they could not approach or confide in family as they did not want to burden them [27].

Positive psychosocial outcomes of caregiving. Some carers in the reviewed papers did acknowledge positive emotions and growth from their caregiving role, such as pride, enhanced learning, and greater empathy [11,17]. In Williams et al.'s [11] study, for example, some carers expressed pride and gratitude in being able to give back to their parents and spouses and said caregiving made them feel valued; it was also noted that having a positive attitude towards caregiving helped them through difficult periods. Ellis et al. [12] found that the ability for caregivers to find positive meaning in their carer experiences (i.e., meaning- 
based coping) was associated with higher caregiver quality of life. However, Ellis et al. also found that more care-recipient comorbidities were associated with lower caregiver meaningbased coping, demonstrating that multimorbidity can make positivity more difficult.

Theme 4: Lack of knowledge and information about care-recipients' medical diagnoses

Uncertainty around understanding and managing care-recipients' symptoms. Carers found it difficult to determine the source of care-recipients' symptoms or discomfort; they were unsure which condition was the cause, or if symptoms were an indication of a separate condition [9,11,24,32]. Carers were unclear about possible relationships between multiple diagnoses and were fearful that medications for one condition may conflict with those for another $[9,11]$. In addition, carers had difficulties knowing how to respond in a 'crisis situation'; they were sometimes unable to determine if symptoms were serious and expressed uncertainty about when to seek medical assistance [9,11]. Carers had to learn over time from their own experience how to differentiate between, and manage, symptoms associated with different illnesses [9,24-25,31]. This placed additional demands on carers as learning about the features of multiple conditions and how they might interact takes longer than learning about a single condition $[11,24]$. Some carers reported low confidence in their ability to provide care, noting that their understanding was insufficient to manage care-recipients' complex needs and treatment [27]. Confidence in their caregiving abilities was important for carers' mental health, with higher self-efficacy associated with positive increases in mental wellbeing [10].

A need for more, and clearer, health care information from professionals. Carers reported a lack of information and guidance from clinicians, including a lack of explanation of carerecipient's diagnoses $[3,9]$ and how to recognise and manage symptoms or side effects $[9,24$, 25,27,33]. Carers expressed that professionals were unwilling to offer advice or to help manage problems unless they were within their speciality [28]. Additionally, due to the 
involvement of multiple medical teams, information that carers did receive was sometimes contradictory, resulting in confusion [9]. Some carers reported that they did receive a lot of information, but that it was 'information overload', difficult to understand, and/or concerned irrelevant topics [28,31]. Carers expressed a need for more, better quality and clearer information from professionals regarding care-recipients' diagnoses and how to manage them $[9,28]$. They also wanted information to help them respond to one condition without having a detrimental impact on the other(s) [9]. Carers who joined support groups or associations to improve their knowledge of their care-recipient's multimorbidities reported that it relieved stress while gaining some control over the situation [11]. In one study, carers of people with comorbid diabetes and kidney disease highlighted that greater access to education strategies focused on specific topics, and more detailed explanations during medical consultations, could improve understanding of the nature, consequences and management of conditions [28].

\section{Theme 5: Difficulties accessing caregiver support and respite services}

Lack of suitable support available. Across several of the included studies, carers of people with multimorbidity acknowledged the need for caregiver support $[3,11,17,29,33]$, with a

carer in one study noting 'the greatest help is to help the caregiver' $[3, p .3]$. Despite their need for support, carers noted that a lack of respite services were available to them [3,28,29,33,34], sometimes due to long waitlists $[3,11,28,34]$ or being deemed ineligible for help [34]. Moreover, support services that were available were described by some carers as inadequate in meeting multimorbidity care needs $[33,34]$. For example, carers in Canada noted that there were an inadequate number of hours of homecare services to meet the multifaceted responsibilities of providing care for someone with multiple conditions [34], and in a study of carers of people with developmental disability and mental illness, it was noted that residential options for care-recipients were inaccessible as they were insufficiently resourced to manage complex needs and challenging behaviours (e.g., aggression) [33]. 
Barriers to accessing available support. Barriers to accessing support were highlighted across included studies, and many carers reported getting no outside help [3,11,17,28,29,34]. Carers reported that care-recipients were often reluctant to accept outside support and to participate in programmes [17,33,34], expressing that it made them feel like an invalid [17]. Carers themselves were also sometimes resistant to support, expressing reluctance to seek help because they believed it would not be helpful to them or the care-recipient [3], or not wanting the disruption to their lives that may come with acceptance of outside help [34]. Finance was also raised by carers a barrier to accessing support services $[3,7,27,28]$.

\section{Research Question 3: What are the research gaps in the existing literature on the experiences and support needs of informal caregivers of people with multimorbidity?}

Limited research on caregivers' psychosocial experiences and support needs in relation to managing multimorbidity, and lack of longitudinal studies. Relatively little research has focused specifically on the experiences and support needs of carers of people with multimorbidity, in contrast to patients with multimorbidity, although this is a recently growing area of interest. More research is needed to gain a deeper understanding of carers' particular and salient difficulties and support needs related specifically to caring for people with multiple chronic conditions. Many of the qualitative papers reviewed tended to focus on pragmatic experiences (e.g., navigating health and care systems, medication management, communication with healthcare professionals); there is thus scope for a greater focus in future studies on more psychosocial aspects of carers' experiences and needs. Additionally, the qualitative papers tended to implicitly adopt a realist epistemological approach, and thus there is scope for more discursive and constructionist research approaches.

This review found very limited longitudinal research examining the experiences and needs of caregivers of people with multimorbidity. Caregiving is for many a long-term role, particularly when caring for a person with a chronic condition, and research has highlighted 
that caregivers' needs can change over the illness trajectory (e.g. Girgis et al., 2013; Halkett et al., 2018). Future longitudinal research could explore how the needs of carers of multimorbid care-recipients may change over time, in order to inform the design and adaptability of interventions; and prospective studies could help to discover predictive factors of poorer outcomes in carers of people with multimorbidity.

\section{Lack of studies exploring the influence of sociodemographic characteristics on the} experiences and needs of carers of people with multimorbidity. Carers in the reviewed papers were predominantly female. Although in general informal caregivers are mostly female, in the UK at least, this is not the case among elderly carers aged over 85 years, where males outnumber females (Office for National Statistics, 2013). As people aged over 80 years have the greatest risk of multimorbidity and thus of providing care for a spouse with multimorbidity (St Sauver et al., 2015), future research, particularly with elderly caregivers, should look to include more male carers, and explore ways in which their experiences and needs may differ from female carers. Few papers considered the influence of caregiver age and relationship to care-recipient on experiences and needs. Two of the included papers found that younger caregivers of people with multimorbidity had higher levels of stress than older caregivers [14], and higher levels of health care task difficulty [18]. Spouses and adult children described different experiences and challenges related to the impact of caregiving on their relationships [11], and being a spousal caregiver was found to predict higher levels of perceived emotional undermining of the carer by the care-recipient [1]. However, relationship type (spouse or non-spouse) was not significantly correlated with health care task difficulty [18]; changes in carers' mental or physical health related quality of life [10]; or agreement between carer and care-recipient on quality of chronic illness care [19]. Findings are limited, and more comparative work is required to explore how the experiences and needs of carers of people with multimorbidity may differ on the basis of carer age or relationship to care- 
recipient. Additionally, the reviewed studies were conducted in several different countries, but almost all were Western, and mostly European. However, as multimorbidity is a global concern (Garin et al., 2016; Pefoyo et al., 2015), future research should include the experiences and needs of caregivers living in non-Western countries. We should note, however, that the lack of non-Western studies may partly reflect the exclusion of non-English language papers in this review.

A need for more studies to explore the qualitative and quantitative differences in experiences and needs of multimorbidity carers and single-condition carers. Of the 18 papers reporting quantitative findings, only three explored how outcomes differed between carers of multimorbid care-recipients and care-recipients with a single chronic condition. It was found that carers of people with multimorbidity spent significantly more time on instrumental activities of daily living than carers of those with a single condition, and the multimorbid carerecipients were significantly more likely to require carer supervision [26]. Carer strain was found to not significantly differ between multimorbidity and single-condition carers [30]; and presence of a dual disorder as opposed to a single mental illness was not a significant predictor of carers' perceptions of relationship quality with the care-recipient [1]. Outcome measures differed across the three papers, but where there were significant findings, carers of people with multimorbidity had poorer outcomes than carers of those with a single illness [26]. No qualitative papers included in the review explored differences in experiences of multimorbidity carers compared with single-condition carers. Some of the experiences highlighted in this review are not unique to caring for a person with multimorbidity, such as reduced social connectedness and high levels of stress, anxiety and depression (e.g. Roland, Jenkins \& Johnson, 2010; Sklenarova et al., 2015; Wawrziczny, Antoine, Ducharme, Kergoat \& Pasquier, 2016). Future research drawing comparisons between multimorbidity carers and singlecondition carers would highlight experiences and needs that are qualitatively different when 
caring for a person with multimorbidity as opposed to a single condition, and could also determine whether any of the challenges and needs that are common in other carer groups are quantitatively worse for multimorbidity carers. Such research would help to inform the adaptability of existing interventions for carers of people with single chronic conditions.

Additionally, a further four quantitative papers considered the number of care-recipient chronic conditions in correlational and regression analyses $[8,12,18,19]$. An increasing number of chronic conditions in multimorbid care-recipients was associated with poorer carer outcomes, including higher caregiver burden [8]; increasing carer scope of assistance [18]; and poorer carer quality of life, mediated by caregiver meaning-based coping [12]. Given that the proportion of people aged $65+$ with four or more chronic conditions is predicted to almost double from 2015 to 2035 (Kingston et al., 2018), it is also of interest to explore how needs may differ within multimorbidity carer samples, with more versus fewer care-recipient conditions.

Very limited research examining supportive interventions for caregivers of people with multimorbidity. The majority of reviewed quantitative studies were observational and only two papers from one study $[20,21]$ reported on an intervention for caregivers of people with multimorbidity. The 'Guided Care' intervention is a model of primary care designed to enhance the quality of health care and improve outcomes for older adults with multimorbidity by integrating a specially trained registered nurse into primary care practices. In this model, the registered nurse works with two to five primary care physicians to provide comprehensive and coordinated health care to meet the complex needs of patients with multimorbidity. The Guided Care Program for Families and Friends (GCPFF) is an element of the Guided Care intervention, offering caregiver group workshops and monthly support sessions for caregivers of older adults with multimorbidity. Although the GCPFF was found to improve the quality of chronic illness care received by the multimorbid care-recipients, and carers reported that it 
was worth their time and they would recommend it to others, the program did not improve carers' depressive symptoms or affect. However, carer participation in the GCPFF workshops and sessions was low, with carers stating competing demands, inconvenient location or time, and/or lack of interest as reasons for non-attendance. One paper examining a telephone coaching intervention for patients with multimorbidity considered as a secondary end-point informal caregiver burden [22]. However, patients' carers were not themselves involved in the intervention and the researchers were unable to obtain data from a sufficient number of carers to draw any conclusions as to the impact on caregiver burden.

\section{Discussion}

This scoping review has synthesised, for the first time, existing published research on the experiences and support needs of informal caregivers of people with multimorbidity. We found 34 papers (27 different studies), reporting both quantitative and qualitative research, though restricted to English-language papers only, the majority of which were rated good quality. The review: (1) demonstrates very recent burgeoning interest in this area, with almost half of the included papers published in just the last four years; (2) highlights common difficulties for informal carers of people with multiple chronic illnesses, including challenges managing multiple medications and side effects, uncertainty around understanding and managing care-recipients' symptoms and a lack of available suitable support; and (3) identifies current gaps in the literature, including a lack of research generally on the psychosocial experiences and needs of caregivers of people with multimorbidity; a lack of studies comparing outcomes and support needs of carers of people with multimorbidity and carers of people with a single condition; and very few studies of interventions which may help support this caregiver group. In this discussion we consider further: the challenges of polypharmacy in multimorbid care-recipients; the need to improve delivery of health care 
information from professionals; and addressing barriers to caregivers of multimorbid patients accessing support.

\section{The challenges of polypharmacy in multimorbid care-recipients}

The use of multiple medications (polypharmacy) is common and increasing among patients with multimorbidity (Duguay et al., 2014; Guthrie, Makubate, Hernandez-Santiago, \& Dreischulte, 2015). Polypharmacy is associated with adverse drug events, drug interactions, cognitive and functional decline, and medication non-adherence (Maher, Hanlon, \& Hajjar, 2014). Much of the polypharmacy literature focuses on patients' experiences and outcomes (e.g., Patterson, Hughes, Kerse, Cardwell, \& Bradley, 2012; Reeve, Wiese, Hendrix, Roberts, \& Shakib, 2013) and the perspectives of professionals (e.g., Schuling, Gebben, Veehof, \& Haaijer-Ruskamp, 2012). However, this review highlights that informal caregivers play a crucial role in managing medicines for multimorbid patients, and that many carers find this responsibility a significant challenge (e.g., due to managing multiple medications and side effects, anxiety around potential drug interactions, patient non-adherence). It is thus important that future research, and particularly that focusing on interventions to reduce polypharmacy or mitigate associated challenges, considers the role and support needs of caregivers.

\section{The need to improve delivery of health care information from professionals}

This review found that many carers experienced difficulties obtaining sufficient and userfriendly health care information from professionals, including receiving too little, too much and unclear information; future research should explore strategies to help address this. One relatively simple strategy which may help mitigate difficulties around information overload and understandability is audio-recording consultations which allows patients and their carers to replay and return to information as often as needed and when convenient for them.

Research shows that when provided, audio-recordings of consultations are listened to, have a 
positive impact on information recall and understanding, and add to understanding of treatments and side effects (Tsulukidze, Durand, Barr, Mead, \& Elwyn, 2014). Wolderslund, Kofoed, Holst and Ammentorp (2015) found that the use of audio-recordings of consultations was positively associated with increasing age and first-time visits to the clinic. Thus, as multimorbidity is most likely to affect the elderly and their spouses (Department of Health, 2012; Waldron, Janke, Bechtel, Ramirez, \& Cohen, 2013), and as this review shows is often associated with sporadic contact with many different professionals, audio-recording consultations may be particularly beneficial in the context of multimorbidity. To date research in this area appears limited to single-illness patient populations; future research should thus explore the potential benefits of audio-recorded consultation interventions for multimorbid patients and their caregivers.

\section{Addressing barriers to caregivers of multimorbid patients accessing support}

This review highlighted a lack of support for caregivers of people with multimorbidity, and the barriers they face in accessing support which is available. Lebrec et al. (2016) found that carers of people with two conditions, compared to those caring for people with one condition, spent significantly more time on caregiving activities, and the only intervention study in the review found carer participation was low, with stated reasons including competing demands and inconvenient location and/or time (Wolff et al., 2009; 2010). eHealth (digital) interventions offer promise in addressing some of the barriers to carers accessing support. Compared to in-person services, e-interventions can be accessed by carers at any time convenient for them 24/7, from any location including their home (avoiding the need to arrange and pay for replacement care and/or travel), and facilitate balancing of competing demands (e.g., carers can break-off and return as needed). Additionally, interventions delivered digitally can typically be offered and scaled-up at lower cost to providers than faceto-face services. Although studies have begun to examine the potential of supportive e- 
interventions for multimorbid patients (e.g., Gray, Miller, Kuluski, \& Cott, 2014; Zulman et al., 2015), research has yet to extend to and include their caregivers. Studies have examined ehealth interventions for carers of people with one condition (mostly dementia) however, and a recent review found high acceptability among carers, with noted benefits including flexibility in access suiting carers' commitments, availability of self-tailored and individualised information and support; and network support through online forums with other carers as well as access to professionals (Sin et al., 2018). Future research might thus fruitfully examine the potential of e-support for carers of people with multimorbidity. As this review highlighted, many carers experience reduced social connectedness yet desire social contact and support; our research team are thus particularly interested in exploring in future work e-interventions to increase social connectedness for carers of people with multiple conditions (e.g. online peer support forums for carers of people with particular combinations of comorbid conditions).

\section{Conclusions}

This novel scoping review has synthesised existing published research on the experiences and support needs of informal caregivers of people with multimorbidity and demonstrates recent burgeoning interest in this area. The review highlights common difficulties for informal carers of people with multiple chronic illnesses, including practical challenges related to managing multiple health care teams, appointments, medications and side effects, and psychosocial challenges including high levels of psychological symptomatology and reduced social connectedness. Current gaps in the literature include a lack of research generally on the psychosocial experiences and needs of caregivers of people with multimorbidity; a lack of studies comparing outcomes and support needs of carers of people with multimorbidity and carers of people with a single condition; and very few studies of interventions which may help support this caregiver group. Future research might fruitfully examine the potential benefits of audio-recorded health care consultations, and digitally-delivered psychosocial interventions 
such as online peer support forums, for supporting and enhancing the caring activities and wellbeing of this caregiver group.

Acknowledgments: This work was supported by a doctoral scholarship awarded to MP from the School of Social Sciences, Leeds Beckett University

Conflicts of Interest: none

\section{References}

Allen, A. P., Curran, E. A., Duggan, Á., Cryan, J. F., Chorcoráin, A. N., Dinan, T. G., ... \& Clarke, G. (2017). A systematic review of the psychobiological burden of informal caregiving for patients with dementia: Focus on cognitive and biological markers of chronic stress. Neuroscience \& Biobehavioral Reviews, 73, 123-164.

Arksey, H., \& O'Malley, L. (2005). Scoping studies: towards a methodological framework. International Journal of Social Research Methodology, 8(1), 19-32.

Aschbacher, K., Mills, P. J., von Känel, R., Hong, S., Mausbach, B. T., Roepke, S. K., ... \& Grant, I. (2008). Effects of depressive and anxious symptoms on norepinephrine and platelet P-selectin responses to acute psychological stress among elderly caregivers. Brain, Behavior, and Immunity, 22(4), 493-502.

Ashley, L., O'Connor, D. B., \& Jones, F. (2011). Effects of emotional disclosure in caregivers: Moderating role of alexithymia. Stress and Health, 27(5), 376-387.

Bähler, C., Huber, C.A., Brüngger, B., \& Reich, O. (2015). Multimorbidity, health care utilisation and costs in an elderly community-dwelling population: a claims data based observational study. BMC Health Services Research, 15(1), 23.

Bayliss, E. A., Steiner, J. F., Fernald, D. H., Crane, L. A., \& Main, D. S. (2003). Descriptions of barriers to self-care by persons with comorbid chronic diseases. The Annals of Family Medicine, 1(1), 15-21.

*Biegel, D. E., Katz-Saltzman, S., Tracy, E. M., \& Townsend, A. (2006). Predictors of Dyadic Relationship Quality of Women in Substance Abuse Treatment. Journal of Dual Diagnosis, 3(1), 87-112.

Braun, V., \& Clarke, V. (2006). Using thematic analysis in psychology. Qualitative Research in Psychology, 3(2), 77-101.

Buckner, L., \& Yeandle, S. (2015). Valuing carers 2015: the rising value of carers support. London: Carers UK. Retrieved from: https://www.researchgate.net/publication/ 283726481_Valuing_Carers_2015_-_The_rising_value_of_carers'_support

*Bunn, F., Burn, A-M., Robinson, L., Poole, M., Rait, G., Brayne, C. .. \& \& Goodman, C. (2017) Healthcare organisation and delivery for people with dementia and 
comorbidity: a qualitative study exploring the views of patients, carers and professionals. BMJ Open, 7(1).

Calderón-Larrañaga, A., Poblador-Plou, B., González-Rubio, F., Gimeno-Feliu, L. A., AbadDíez, J. M., \& Prados-Torres, A. (2012). Multimorbidity, polypharmacy, referrals, and adverse drug events: are we doing things well?. Br J Gen Pract, 62(605), e821-e826.

*Chia, Y. H., \& Lunsky, Y. (2003). Dual diagnosis and access to services. Journal of Developmental Disabilities, 10, 79-82.

*Clark, R. E. (1994). Family costs associated with severe mental illness and substance use. Psychiatric Services, 45(8), 808-813.

*Clark, R. E. (2001). Family support and substance use outcomes for persons with mental illness and substance use disorders. Schizophrenia Bulletin, 27(1), 93.

*Clark, R. E., \& Drake, R. E. (1994). Expenditures of time and money by families of people with severe mental illness and substance use disorders. Community Mental Health Journal, 30(2), 145-163.

*Corvin, J., Chan, I., Tezak, A., Carpenter, K., Aguado Loi, C., Gonzales, J., \& Hoare, I. (2017). Caring for Individuals with Chronic Illness and Minor Depression: Latino Perceptions of Caregiver Burden. Journal of Gerontological Social Work, 60(1), 79-95.

*Dauphinot, V., Ravier, A., Novais, T., Delphin-Combe, F., Moutet, C., Xie, J., ... \& KrolakSalmon, P. (2016). Relationship between comorbidities in patients with cognitive complaint and caregiver burden: a cross-sectional study. Journal of the American Medical Directors Association, 17(3), 232-237.

Deeken, J. F., Taylor, K. L., Mangan, P., Yabroff, K. R., \& Ingham, J. M. (2003). Care for the caregivers: a review of self-report instruments developed to measure the burden, needs, and quality of life of informal caregivers. Journal of Pain and Symptom management, 26(4), 922-953.

Department of Health. (2012). Long term conditions compendium of information: third edition. Leeds, UK. Retrieved from: https://assets.publishing.service.gov.uk/ government/uploads/system/uploads/attachment_data/file/216528/dh_134486.pdf

Dixon-Woods, M., Agarwal, S., Jones, D., Young, B., \& Sutton, A. (2005). Synthesising qualitative and quantitative evidence: a review of possible methods. Journal of Health Services Research \& Policy, 10(1), 45-53.

Doessing, A., \& Burau, V. (2015). Care coordination of multimorbidity: a scoping study. Journal of Comorbidity, 5(1), 15-28.

*Doos, L., Bradley, E., Rushton, C. A., Satchithananda, D., Davies, S. J., \& Kadam, U. T. (2014). Heart failure and chronic obstructive pulmonary disease multimorbidity at hospital discharge transition: a study of patient and carer experience. Health Expectations, 18(6), 2401-2412.

*Duggleby, W., Williams, A., Ghosh, S., Moquin, H., Ploeg, J., Markle-Reid, M., \& Peacock, S. (2016). Factors influencing changes in health-related quality of life of caregivers of 
persons with multiple chronic conditions. Health and Quality of Life Outcomes, 14(1), 81.

Duguay, C., Gallagher, F., \& Fortin, M. (2014). The experience of adults with multimorbidity: a qualitative study. Journal of Comorbidity, 4(1), 11-21.

*Ellis, K. R., Janevic, M. R., Kershaw, T., Caldwell, C. H., Janz, N. K., \& Northouse, L. (2017). Meaning-based coping, chronic conditions and quality of life in advanced cancer \& caregiving. Psycho-oncology, 26(9), 1316-1323.

*El-Mallakh, P., Yates, B. E., \& Adkins, S. (2013). Family caregiving for adults with schizophrenia and diabetes mellitus. Issues in Mental Health Nursing, 34(8), 566-577.

*Espie, C. A., Watkins, J., Curtice, L., Espie, A., Duncan, R., Ryan, J. A., ... \& Sterrick, M. (2003). Psychopathology in people with epilepsy and intellectual disability; an investigation of potential explanatory variables. Journal of Neurology, Neurosurgery \& Psychiatry, 74(11), 1485-1492.

Fortin, M., Soubhi, H., Hudon, C., Bayliss, E. A., \& van den Akker, M. (2007). Multimorbidity's many challenges. BMJ: British Medical Journal, 334(7602), 1016.

*García-Fernández, F. P., Arrabal-Orpez, M. J., Rodríguez-Torres, M. D. C., Gila-Selas, C., Carrascosa-García, I., \& Laguna-Parras, J. M. (2014). Effect of hospital case-manager nurses on the level of dependence, satisfaction and caregiver burden in patients with complex chronic disease. Journal of Clinical Nursing, 23(19-20), 2814-2821.

Garin, N., Koyanagi, A., Chatterji, S., Tyrovolas, S., Olaya, B., Leonardi, M., ... \& Haro, J. M. (2016). Global multimorbidity patterns: a cross-sectional, population-based, multicountry study. Journals of Gerontology Series A: Biomedical Sciences and Medical Sciences, 71(2), 205-214.

*Gill, A., Kuluski, K., Jaakkimainen, L., Naganathan, G., Upshur, R., \& Wodchis, W. P. (2014). "Where Do We Go from Here?” Health System Frustrations Expressed by Patients with Multimorbidity, Their Caregivers and Family Physicians. Healthcare Policy, 9(4), 73-89.

*Giovannetti, E. R., Reider, L., Wolff, J. L., Frick, K. D., Boult, C., Steinwachs, D., \& Boyd, C. M. (2013). Do older patients and their family caregivers agree about the quality of chronic illness care?. International Journal for Quality in Health Care, 25(5), 515-524.

*Giovannetti, E. R., Wolff, J. L., Xue, Q. L., Weiss, C. O., Leff, B., Boult, C., ... \& Boyd, C. M. (2011). Difficulty Assisting with Health Care Tasks Among Caregivers of Multimorbid Older Adults. Journal of General Internal Medicine, 27(1), 37-44.

Girgis, A., Lambert, S. D., McElduff, P., Bonevski, B., Lecathelinais, C., Boyes, A., \& Stacey, F. (2013). Some things change, some things stay the same: a longitudinal analysis of cancer caregivers' unmet supportive care needs. Psycho-Oncology, 22(7), 1557-1564.

Glynn, L. G., Valderas, J. M., Healy, P., Burke, E., Newell, J., Gillespie, P., \& Murphy, A. W. (2011). The prevalence of multimorbidity in primary care and its effect on health care utilization and cost. Family Practice, 28(5), 516-523. 
*González-Ortega, M., Gené-Badia, J., Kostov, B., García-Valdecasas, V., \& Pérez-Martín, C. (2016). Randomized trial to reduce emergency visits or hospital admissions using telephone coaching to complex patients. Family Practice, 34(2), 219-226.

Grant, M. J., \& Booth, A. (2009). A typology of reviews: an analysis of 14 review types and associated methodologies. Health Information \& Libraries Journal, 26(2), 91-108.

Gray, C. S., Miller, D., Kuluski, K., \& Cott, C. (2014). Tying eHealth tools to patient needs: exploring the use of ehealth for community-dwelling patients with complex chronic disease and disability. JMIR Research Protocols, 3(4).

Guthrie, B., Makubate, B., Hernandez-Santiago, V., \& Dreischulte, T. (2015). The rising tide of polypharmacy and drug-drug interactions: population database analysis 19952010. BMC medicine, 13(1), 74.

Hagger, M. S., Koch, S., Chatzisarantis, N. L., \& Orbell, S. (2017). The common sense model of self-regulation: Meta-analysis and test of a process model. Psychological Bulletin, 143(11), 1117.

Halkett, G. K. B., Lobb, E. A., Shaw, T., Sinclair, M. M., Miller, L., Hovey, E., \& Nowak, A. K. (2018). Do carer's levels of unmet needs change over time when caring for patients diagnosed with high-grade glioma and how are these needs correlated with distress?. Supportive Care in Cancer, 26(1), 275-286.

Harding, R., List, S., Epiphaniou, E., \& Jones, H. (2012). How can informal caregivers in cancer and palliative care be supported? An updated systematic literature review of interventions and their effectiveness. Palliative medicine, 26(1), 7-22.

*Hjelm, M., Holmgren, A. C., Willman, A., Bohman, D., \& Holst, G. (2015). Family members of older persons with multi-morbidity and their experiences of case managers in Sweden: an interpretive phenomenological approach. International Journal of Integrated Care, 15(1).

*Jowsey, T., Jeon, Y. H., Dugdale, P., Glasgow, N. J., Kljakovic, M., \& Usherwood, T. (2009). Challenges for co-morbid chronic illness care and policy in Australia: a qualitative study. Australia and New Zealand Health Policy, 6(1), 22.

Kim, Y., Carver, C. S., Rocha-Lima, C., \& Shaffer, K. M. (2013). Depressive symptoms among caregivers of colorectal cancer patients during the first year since diagnosis: a longitudinal investigation. Psycho-Oncology, 22(2), 362-367.

Kingston, A., Robinson, L., Booth, H., Knapp, M., Jagger, C. (2018). Projections of multimorbidity in the older population in England to 2035: estimates from the Population Ageing and Care Simulation (PACSim) model. Age and ageing, 47(3), 374-380.

Koller, D., Schön, G., Schäfer, I., Glaeske, G., van den Bussche, H., \& Hansen, H. (2014). Multimorbidity and long-term care dependency - a five-year follow-up. BMC geriatrics, 14(1), 70. 
Koroukian, S. M., Warner, D. F., Owusu, C., \& Given, C. W. (2015). Multimorbidity Redefined: Prospective Health Outcomes and the Cumulative Effect of Co-Occurring Conditions. Preventing Chronic Disease, 12, e55.

*Kuluski, K., Gill, A., Naganathan, G., Upshur, R., Jaakkimainen, R. L., \& Wodchis, W. P. (2013). A qualitative descriptive study on the alignment of care goals between older persons with multi-morbidities, their family physicians and informal caregivers. $B M C$ Family Practice, 14(1), 133.

Lavela, S. L., \& Ather, N. (2010). Psychological health in older adult spousal caregivers of older adults. Chronic Illness, 6(1), 67-80.

*Lawrence, V., Murray, J., \& Banerjee, S. (2009). "Out of sight, out of mind": a qualitative study of visual impairment and dementia from three perspectives. International Psychogeriatrics, 21(3), 511-518.

*Lebrec, J., Ascher-Svanum, H., Chen, Y. F., Reed, C., Kahle-Wrobleski, K., Hake, A. M., ... \& Kendall, D. M. (2016). Effect of diabetes on caregiver burden in an observational study of individuals with Alzheimer's disease. BMC Geriatrics, 16(1), 93.

*Lee, V. Y., Seah, W. Y., Kang, A. W., Khoo, E. Y., Mooppil, N., \& Griva, K. (2016). Managing multiple chronic conditions in Singapore-Exploring the perspectives and experiences of family caregivers of patients with diabetes and end stage renal disease on haemodialysis. Psychology \& Health, 31(10), 1220-1236.

Lehnert, T., Heider, D., Leicht, H., Heinrich, S., Corrieri, S., Luppa, M., ... \& König, H. H. (2011). Health care utilization and costs of elderly persons with multiple chronic conditions. Medical Care Research and Review, 68(4), 387-420.

Levac, D., Colquhoun, H., \& O’Brien, K. K. (2010). Scoping studies: advancing the methodology. Implementation Science, 5(1), 1-9.

Liddy, C., Blazkho, V., \& Mill, K. (2014). Challenges of self-management when living with multiple chronic conditions: systematic review of the qualitative literature. Canadian Family Physician, 60(12), 1123-1133.

*Lo, C., Ilic, D., Teede, H., Cass, A., Fulcher, G., Gallagher, M., ... \& Polkinghorne, K. (2016). The perspectives of patients on health-care for Co-Morbid Diabetes and Chronic Kidney Disease: a qualitative study. PloS one, 11(1), e0146615.

Lovell, B., \& Wetherell, M. A. (2011). The cost of caregiving: Endocrine and immune implications in elderly and non elderly caregivers. Neuroscience \& Biobehavioral Reviews, 35(6), 1342-1352.

Maher, R. L., Hanlon, J., \& Hajjar, E. R. (2014). Clinical consequences of polypharmacy in elderly. Expert Opinion on Drug Safety, 13(1), 57-65.

Marengoni, A., Angleman, S., Melis, R., Mangialasche, F., Karp, A., Garmen, A., ... \& Fratiglioni, L. (2011). Aging with multimorbidity: a systematic review of the literature. Ageing research reviews, 10(4), 430-439. 
*Mason, B., Nanton, V., Epiphaniou, E., Murray, S. A., Donaldson, A., Shipman, C., ... \& Boyd, K. (2016). 'My body's falling apart.' Understanding the experiences of patients with advanced multimorbidity to improve care: serial interviews with patients and carers. BMJ Supportive \& Palliative Care, 6, 60-65.

*Matthews, T., Weston, N., Baxter, H., Felce, D., \& Kerr, M. (2008). A general practicebased prevalence study of epilepsy among adults with intellectual disabilities and of its association with psychiatric disorder, behaviour disturbance and carer stress. Journal of Intellectual Disability Research, 52(2), 163-173.

*Mengoni, S. E., Gates, B., Parkes, G., Wellsted, D., Barton, G., Ring, H., ... \& Durand, M. A. (2016). "Sometimes, it just stops me from doing anything": A qualitative exploration of epilepsy management in people with intellectual disabilities and their carers. Epilepsy \& Behavior, 64, 133-139.

Mittelman, M. (2005). Taking care of the caregivers. Current Opinion in Psychiatry, 18(6), 633-639.

Moffat, K., \& Mercer, S. W. (2015). Challenges of managing people with multimorbidity in today's healthcare systems. BMC family practice, 16(1), 129.

*Morales-Asencio, J. M., Martin-Santos, F., Kaknani, S., Morilla-Herrera, J., Cuevas Fernández-Gallego, M., García-Mayor, S., ... \& Morales-Gil, I. M. (2016). Living with chronicity and complexity: Lessons for redesigning case management from patients' life stories-a qualitative study. Journal of Evaluation in Clinical Practice, 22(1), 122132.

Murphy, N. A., Christian, B., Caplin, D. A., \& Young, P. C. (2007). The health of caregivers for children with disabilities: caregiver perspectives. Child: Care, Health and Development, 33(2), 180-187.

National Alliance for Caregiving (2009). Caregiving in the U.S. 2009. Report. Retrieved from http://www.caregiving.org/data/Caregiving_in_the_US_2009_full_report.pdf

National Institute for Health and Care Excellence. (2016). Multimorbidity: clinical assessment and management (NICE Guideline NG56). Retrieved from https://www.nice.org.uk/guidance/ng56

*Nicholas, D. B., Calhoun, A., McLaughlin, A. M., Shankar, J., Kreitzer, L., \& Uzande, M. (2017). Care Experiences of Adults With a Dual Diagnosis and Their Family Caregivers. Global Qualitative Nursing Research, 4, 2333393617721646.

Office for National Statistics (2013). 2011 Census. Detailed Characteristics for England and Wales. UK Data Service.

Oken, B. S., Fonareva, I., \& Wahbeh, H. (2011). Stress-related cognitive dysfunction in dementia caregivers. Journal of Geriatric Psychiatry and Neurology, 24(4), 191-198.

Patterson, S. M., Hughes, C., Kerse, N., Cardwell, C. R., \& Bradley, M. C. (2012). Interventions to improve the appropriate use of polypharmacy for older people. Cochrane Database of Systematic Reviews, 5(5). 
Pefoyo, A.J., Bronskill, S.E., Gruneir, A., Calzavara, A., Thavorn K, Petrosyan, Y., ... \& Wodchis, W.P. (2015). The increasing burden and complexity of multimorbidity. BMC Public Health, 15:415.

*Ploeg, J., Matthew-Maich, N., Fraser, K., Dufour, S., McAiney, C., Kaasalainen, S., ... \& Emili, A. (2017). Managing multiple chronic conditions in the community: a Canadian qualitative study of the experiences of older adults, family caregivers and healthcare providers. BMC Geriatrics, 17(1), 40.

Pluye, P., Gagnon, M. P., Griffiths, F., \& Johnson-Lafleur, J. (2009). A scoring system for appraising mixed methods research, and concomitantly appraising qualitative, quantitative and mixed methods primary studies in Mixed Studies Reviews. International Journal of Nursing Studies, 46(4), 529-546.

Pluye, P., Robert, E., Cargo, M., Bartlett, G., O'Cathain, A., Griffiths, F., ... \& Rousseau, M. C. (2011). Proposal: A mixed methods appraisal tool for systematic mixed studies reviews. Retrieved 2018 from http://mixedmethodsappraisaltoolpublic.pbworks.com.

Reeve, E., Wiese, M. D., Hendrix, I., Roberts, M. S., \& Shakib, S. (2013). People's attitudes, beliefs, and experiences regarding polypharmacy and willingness to deprescribe. Journal of the American Geriatrics Society, 61(9), 1508-1514.

Roland, K. P., Jenkins, M. E., \& Johnson, A. M. (2010). An exploration of the burden experienced by spousal caregivers of individuals with Parkinson's disease. Movement Disorders, 25(2), 189-193.

Røthing, M., Malterud, K., \& Frich, J. C. (2015). Balancing needs as a family caregiver in Huntington's disease: a qualitative interview study. Health \& Social Care in the Community, 23(5), 569-576.

Schuling, J., Gebben, H., Veehof, L. J. G., \& Haaijer-Ruskamp, F. M. (2012). Deprescribing medication in very elderly patients with multimorbidity: the view of Dutch GPs. A qualitative study. BMC Family Practice, 13(1), 56.

Signal, L., Semper, K., Stairmand, J., Davies, C., Millar, E., Dowell, T., ... \& Sarfati, D. (2017). A walking stick in one hand and a chainsaw in the other: patients' perspectives of living with multimorbidity.

Sin, J., Gillard, S., Henderson, C., Spain, D., Cornelius, V., \& Chen, T. (2018). eHealth interventions for family carers of people with long term illness: A promising approach?. Clinical Psychology Review, 60, 109-125.

Sinnott, C., Mc Hugh, S., Browne, J., \& Bradley, C. (2013). GPs' perspectives on the management of patients with multimorbidity: systematic review and synthesis of qualitative research. BMJ Open, 3(9), e003610.

Sklenarova, H., Krümpelmann, A., Haun, M. W., Friederich, H. C., Huber, J., Thomas, M., ... \& Hartmann, M. (2015). When do we need to care about the caregiver? Supportive care needs, anxiety, and depression among informal caregivers of patients with cancer and cancer survivors. Cancer, 121(9), 1513-1519. 
St Sauver, J. L., Boyd, C. M., Grossardt, B. R., Bobo, W. V., Rutten, L. J. F., Roger, V. L., ... \& Rocca, W. A. (2015). Risk of developing multimorbidity across all ages in an historical cohort study: differences by sex and ethnicity. BMJ Open, 5(2), e006413.

Thompson, C. A., Spilsbury, K., Hall, J., Birks, Y., Barnes, C., \& Adamson, J. (2007). Systematic review of information and support interventions for caregivers of people with dementia. BMC geriatrics, 7(1), 18.

Tinetti, M. E., Fried, T. R., \& Boyd, C. M. (2012). Designing health care for the most common chronic condition-multimorbidity. JAMA, 307(23), 2493-2494.

Tsulukidze, M., Durand, M. A., Barr, P. J., Mead, T., \& Elwyn, G. (2014). Providing recording of clinical consultation to patients-a highly valued but underutilized intervention: a scoping review. Patient Education and Counselling, 95(3), 297-304.

Van Oostrom, S. H., Picavet, H. S. J., De Bruin, S. R., Stirbu, I., Korevaar, J. C., Schellevis, F. G., \& Baan, C. A. (2014). Multimorbidity of chronic diseases and health care utilization in general practice. BMC family practice, 15(1), 61.

Van Ryn, M., Sanders, S., Kahn, K., Van Houtven, C., Griffin, J. M., Martin, M., ... \& Rowland, J. (2011). Objective burden, resources, and other stressors among informal cancer caregivers: a hidden quality issue?. Psycho-Oncology, 20(1), 44-52.

Vogeli, C., Shields, A. E., Lee, T. A., Gibson, T. B., Marder, W. D., Weiss, K. B., \& Blumenthal, D. (2007). Multiple chronic conditions: prevalence, health consequences, and implications for quality, care management, and costs. Journal of General Internal Medicine, 22(3), 391-395.

Waldron, E. A., Janke, E. A., Bechtel, C. F., Ramirez, M., \& Cohen, A. (2013). A systematic review of psychosocial interventions to improve cancer caregiver quality of life. Psycho-Oncology, 22(6), 1200-1207.

Wawrziczny, E., Antoine, P., Ducharme, F., Kergoat, M. J., \& Pasquier, F. (2016). Couples' experiences with early-onset dementia: An interpretative phenomenological analysis of dyadic dynamics. Dementia, 15(5), 1082-1099.

*Williams, A., Sethi, B., Duggleby, W., Ploeg, J., Markle-Reid, M., Peacock, S., \& Ghosh, S. (2016). A Canadian qualitative study exploring the diversity of the experience of family caregivers of older adults with multiple chronic conditions using a social location perspective. International Journal for Equity in Health, 15(1), 40.

Wolderslund, M., Kofoed, P. E., Holst, R., \& Ammentorp, J. (2015). Patients' use of digital audio recordings in four different outpatient clinics. International Journal for Quality in Health Care, 27(6), 466-472.

*Wolff, J. L., Giovannetti, E. R., Boyd, C. M., Reider, L., Palmer, S., Scharfstein, D., ... \& Frick, K. D. (2010). Effects of guided care on family caregivers. The Gerontologist, 50(4), 459-470.

*Wolff, J. L., Rand-Giovannetti, E., Palmer, S., Wegener, S., Reider, L., Frey, K., ... \& Boult, C. (2009). Caregiving and chronic care: the guided care program for families and 
friends. Journals of Gerontology Series A: Biomedical Sciences and Medical Sciences, 64(7), 785-791.

Wong, M. C., Liu, J., Zhou, S., Li, S., Su, X., Wang, H. H., ... \& Lau, J. T. (2014). The association between multimorbidity and poor adherence with cardiovascular medications. International journal of cardiology, 177(2), 477-482.

Zulman, D. M., Jenchura, E. C., Cohen, D. M., Lewis, E. T., Houston, T. K., \& Asch, S. M. (2015). How can eHealth technology address challenges related to multimorbidity? Perspectives from patients with multiple chronic conditions. Journal of General Internal Medicine, 30(8), 1063-1070. 
Hits from primary database searches

( $K=2674$, de-duplicated)

Exclusion by title and abstract screening $(k=2574)$

Secondary searches $(k=0)$

Exclusion by full-text screening $(k=66)$

Final included papers $(k=34)$, reporting findings from 27 different studies

\section{Reasons for exclusion*:}

Lack of explicit focus on caregivers $(k=14)$; Carerecipient group did not have multiple conditions $(k=14)$; One or more conditions were not diagnosed $(k=6)$; One or more conditions were not classed as chronic $(k=6)$; One condition was a symptom of the other rather than a separate chronic condition $(k=3)$; Only a proportion of the carerecipients had multimorbidity $(k$ $=2$ ); Care-recipient group were children $(k=1)$; Full text was not published in English $(k=$ 12); Full text was not published $(k=4)$; Unable to access full text $(k=1)$; Not primary empirical research $(k=6)$.

*Some papers were excluded for more than one reason

Figure 1. Flow diagram of the search, screening and selection process 


Poor communication
and coordination
between different
health care teams

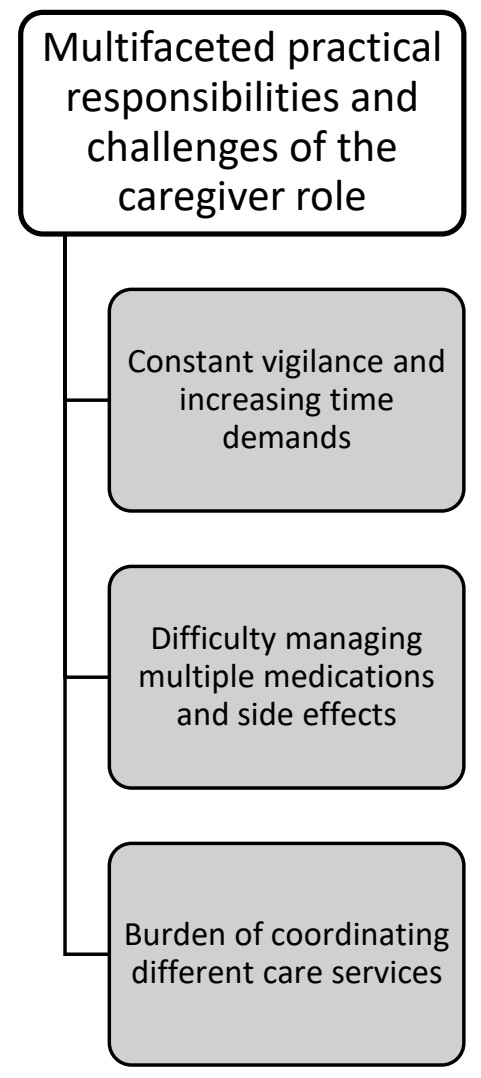

Emotional and psychosocial burden of the caregiver role

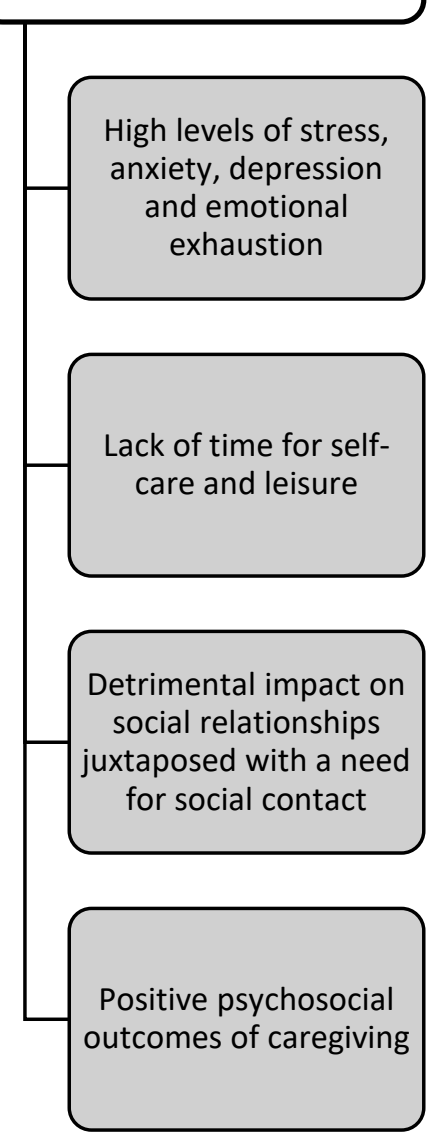

Lack of knowledge and information about care-recipients' medical diagnoses

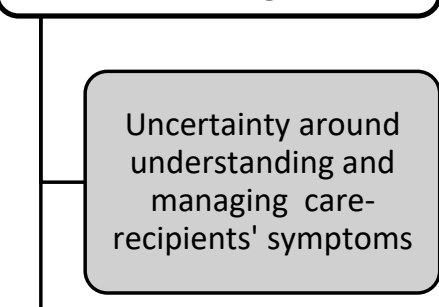

A need for more, and clearer, health care information from professionals
Difficulties accessing caregiver support and respite services

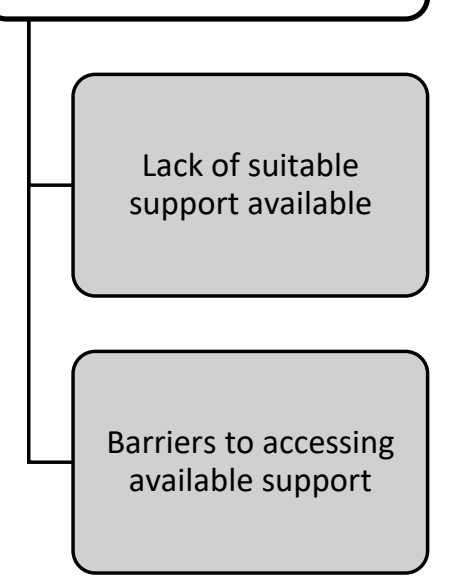

Figure 2. Key themes and sub-themes identified in the reviewed studies' findings concerning the experiences and support needs of caregivers of people with multimorbidity. 
Table 1. Summary of the characteristics and key findings of the papers included in the scoping review

\begin{tabular}{|c|c|c|c|c|c|c|c|c|c|}
\hline ID & Quality $^{1}$ & $\begin{array}{l}\text { Authors \& } \\
\text { Date }\end{array}$ & Location & $\begin{array}{c}\text { Care-recipient } \\
\text { multimorbidity }\end{array}$ & $\begin{array}{l}\text { Caregiver } \\
\mathbf{N}\end{array}$ & Caregiver age & $\begin{array}{l}\text { Relationship to care- } \\
\text { recipient }\end{array}$ & Study design $^{2}$ & Key findings \\
\hline [1] & *** & $\begin{array}{l}\text { Biegel et al. } \\
2006\end{array}$ & US & $\begin{array}{l}\text { Mental illness and } \\
\text { substance use disorder }\end{array}$ & 82 & $\begin{array}{l}\mathrm{M}=40 \text { years } \\
\text { (range 18-77) }\end{array}$ & $\begin{array}{l}\text { Reported as: Spouse } \\
(31.7 \%) \text {; sibling } \\
(23.2 \%) \text {; parent } \\
(19.5 \%) \text {; adult child } \\
(11 \%) \text {; other relative } \\
(14.6 \%)\end{array}$ & $\begin{array}{l}\text { Quantitative } \\
\text { cross-sectional } \\
\text { questionnaires }\end{array}$ & $\begin{array}{l}\text { Carers had moderate levels of worry and displeasure, } \\
\text { lower levels of stigma. Almost two fifths had a } \\
\text { depressive symptomatology scale score indicating } \\
\text { risk for clinical depression. Poorer relationship } \\
\text { quality between carer and care-recipient was } \\
\text { predicted by greater care-recipient behavioural } \\
\text { problems and by the family caregiver being a } \\
\text { significant other of the care-recipient. Having a dual } \\
\text { disorder as compared to a substance use disorder } \\
\text { only was not a predictor of relationship quality. }\end{array}$ \\
\hline [2] & $* *$ & Bunn et al. 2017 & UK & $\begin{array}{l}\text { Dementia and: } \\
\text { diabetes, stroke or } \\
\text { vision impairment }\end{array}$ & 33 & $\begin{array}{l}\text { Mdn = 65 years } \\
\text { (range 46-90) }\end{array}$ & $\begin{array}{l}\text { Reported as: Spouse } \\
(64 \%) \text {; adult child } \\
(14 \%)\end{array}$ & $\begin{array}{l}\text { Qualitative } \\
\text { dyadic interviews } \\
\text { (patient-carer } \\
\text { dyads) }\end{array}$ & $\begin{array}{l}\text { Carers had a vital role in coordinating care and } \\
\text { navigating healthcare systems, e.g. managing } \\
\text { appointments, keeping records of test results and } \\
\text { medication, negotiating access to services for their } \\
\text { care-recipients and transferring information between } \\
\text { different professionals. As care-recipients' dementia } \\
\text { worsened, responsibility for managing care moved } \\
\text { from the care-recipient to carer. There was poor } \\
\text { communication and collaboration across specialities, } \\
\text { particularly across mental and physical health } \\
\text { services. * }\end{array}$ \\
\hline [3] & $*$ & $\begin{array}{l}\text { Chia \& Lunsky } \\
2003\end{array}$ & Canada & $\begin{array}{l}\text { Developmental } \\
\text { disability and mental } \\
\text { illness }\end{array}$ & 7 & Not reported & Parent $(\mathrm{n}=7)$ & $\begin{array}{l}\text { Qualitative } \\
\text { individual } \\
\text { interviews }\end{array}$ & $\begin{array}{l}\text { Carers were concerned about the lack of } \\
\text { communication and explanation of the diagnoses; } \\
\text { and about their care-recipient's ability to } \\
\text { communicate their needs to service providers. Carers } \\
\text { reported challenges accessing services. Carers } \\
\text { emphasised the need for support but reported } \\
\text { difficulties in finding appropriate service providers; }\end{array}$ \\
\hline
\end{tabular}




\begin{tabular}{|c|c|c|c|c|c|c|c|c|c|}
\hline & & & & & & & & & $\begin{array}{l}\text { long wait times; lack of readily available services; } \\
\text { and financial concerns. }\end{array}$ \\
\hline [4] & $* * * *$ & Clark, 1994 & US & $\begin{array}{l}\text { Mental illness and } \\
\text { substance use disorder }\end{array}$ & 119 & $\begin{array}{l}\mathrm{M}=59.3 \text { years } \\
\text { (range not } \\
\text { reported) }\end{array}$ & Parent $(\mathrm{n}=119)$ & $\begin{array}{l}\text { Quantitative } \\
\text { structured } \\
\text { interviews, } \\
\text { including with } \\
\text { matched } \\
\text { comparator group } \\
\text { of non-carers }\end{array}$ & $\begin{array}{l}\text { Carers reported that they gave significantly more } \\
\text { money and time to their adult child than parents of } \\
\text { adults with no chronic illnesses. }\end{array}$ \\
\hline [5] & $* * *$ & Clark, 2001 & US & $\begin{array}{l}\text { Mental illness and } \\
\text { substance use disorder }\end{array}$ & 174 & $\begin{array}{l}\mathrm{M}=56 \text { years } \\
\text { (range } 25-88 \text { ) }\end{array}$ & $\begin{array}{l}\text { Reported as: Parent } \\
(67 \%) ; \text { sibling }(17 \%) ; \\
\text { grandparent, spouse, } \\
\text { child or other relative } \\
(11.5 \%)\end{array}$ & $\begin{array}{l}\text { Quantitative } \\
\text { structured } \\
\text { longitudinal } \\
\text { interviews }\end{array}$ & $\begin{array}{l}\text { Higher carer economic support and more caregiving } \\
\text { hours were significantly associated with care- } \\
\text { recipient recovery (substance use reduction). }\end{array}$ \\
\hline [6] & $*$ & $\begin{array}{l}\text { Clark \& Drake, } \\
1994\end{array}$ & US & $\begin{array}{l}\text { Mental illness and } \\
\text { substance use disorder }\end{array}$ & 169 & Not reported & $\begin{array}{l}\text { Reported as: } \\
\text { Parent }(\mathrm{n}=119) \\
\text { sibling }(\mathrm{n}=30) \\
\text { spouse, grandparent, } \\
\text { child or other relative } \\
(\mathrm{n}=20)\end{array}$ & $\begin{array}{l}\text { Quantitative } \\
\text { structured } \\
\text { longitudinal } \\
\text { interviews }\end{array}$ & $\begin{array}{l}\text { Carers of care-recipients who lived with them spent } \\
\text { significantly more time caregiving than those who } \\
\text { lived apart. Care-recipients with more severe alcohol } \\
\text { problems were more likely to live with carers. More } \\
\text { severe current substance abuse reduced family } \\
\text { spending but not direct caregiving. }\end{array}$ \\
\hline [7] & $* * *$ & $\begin{array}{l}\text { Corvin et al. } \\
2017\end{array}$ & US & $\begin{array}{l}\text { Minor depression and } \\
\text { comorbid chronic } \\
\text { conditions }\end{array}$ & 17 & Not reported & Not reported & $\begin{array}{l}\text { Qualitative } \\
\text { focus groups }\end{array}$ & $\begin{array}{l}\text { Carers reported increased financial insecurity and the } \\
\text { importance of financial resources in the successful } \\
\text { management of the multimorbidities; challenges } \\
\text { balancing the competing demands of caregiving, } \\
\text { household responsibilities and their own needs; and } \\
\text { increased emotional distress. Carers discussed the } \\
\text { role of community support and its potential for } \\
\text { enhancing their caregiving efforts and facilitating } \\
\text { improved health among care-recipients. }\end{array}$ \\
\hline [8] & $* *$ & $\begin{array}{l}\text { Dauphinot et al. } \\
2016\end{array}$ & France & $\begin{array}{l}\text { Cognitive impairment } \\
\text { and comorbid } \\
\text { conditions }\end{array}$ & 1300 & Not reported & $\begin{array}{l}\text { Reported as: Spouse ( } \mathrm{n} \\
=565) \text {; adult child or } \\
\text { grandchild }(\mathrm{n}=611) \text {; }\end{array}$ & $\begin{array}{l}\text { Quantitative } \\
\text { cross-sectional } \\
\text { questionnaires }\end{array}$ & $\begin{array}{l}\text { Caregiver burden was significantly positively } \\
\text { associated with comorbidities. }\end{array}$ \\
\hline
\end{tabular}




\begin{tabular}{|c|c|c|c|c|c|c|c|c|c|}
\hline & & & & & & & $\begin{array}{l}\text { sibling or } \\
\text { niece/nephew ( }(\mathrm{n}=39) \text {; } \\
\text { other }(\mathrm{n}=85)\end{array}$ & & \\
\hline & $* *$ & Doos et al. 2014 & UK & $\begin{array}{l}\text { Heart failure and } \\
\text { COPD }\end{array}$ & 5 & Not reported & Not reported & $\begin{array}{l}\text { Mixed-methods- } \\
\text { Qualitative } \\
\text { element } \\
\text { interviews }\end{array}$ & $\begin{array}{l}\text { Carers experienced poor clarity of information on } \\
\text { diagnosis and symptoms. They reported receiving } \\
\text { contradicting information and were uncertain if } \\
\text { reacting to the symptoms of one condition could } \\
\text { impact the other. Carers commonly took lead role in } \\
\text { managing compliance with medication regimen, but } \\
\text { participants reported little understanding about the } \\
\text { potential for treatments to interact. } \\
\text { Carers also experienced poor communication within } \\
\text { and between team members; and poor } \\
\text { communication between healthcare professionals, } \\
\text { care-recipients and carers in hospital and post- } \\
\text { discharge. * }\end{array}$ \\
\hline [10] & $* * *$ & $\begin{array}{l}\text { Duggleby et al. } \\
2016\end{array}$ & Canada & $\begin{array}{l}\text { Multiple chronic } \\
\text { conditions (any) }\end{array}$ & 185 & $\begin{array}{l}\text { Reported as: } \\
65+(\mathrm{n}=127) \\
<65(\mathrm{n}=58)\end{array}$ & $\begin{array}{l}\text { Spouse }(\mathrm{n}=80) \text {; adult } \\
\text { child }(\mathrm{n}=83) \text {; parent } \\
(\mathrm{n}=7) \text {; sibling }(\mathrm{n}=2) \text {; } \\
\text { other }(\mathrm{n}=13)\end{array}$ & $\begin{array}{l}\text { Mixed-methods- } \\
\text { Quantitative } \\
\text { element } \\
\text { prospective } \\
\text { questionnaires } \\
\text { (two time-points, } \\
\text { 6-months apart) }\end{array}$ & $\begin{array}{l}\text { Improvement in carer mental health (from baseline to } \\
6 \text { months) was significantly positively associated } \\
\text { with general self-efficacy and masculine gender } \\
\text { identity, and significantly negatively associated with } \\
\text { caregiver burden. }\end{array}$ \\
\hline [11] & $* * *$ & $\begin{array}{l}\text { Williams et al. } \\
2016\end{array}$ & Canada & $\begin{array}{l}\text { Multiple chronic } \\
\text { conditions (any) }\end{array}$ & 40 & $\begin{array}{l}\text { Reported as: } \\
<45(\mathrm{n}=4) \\
46-50(\mathrm{n}=3) \\
51-55(\mathrm{n}=7) \\
56-60(\mathrm{n}=6) \\
61-65(\mathrm{n}=3) \\
66-70(\mathrm{n}=4) \\
71-75(\mathrm{n}=4)\end{array}$ & $\begin{array}{l}\text { Spouse ( } \mathrm{n}=18) \text {; adult } \\
\text { child }(\mathrm{n}=18) \text {; parent } \\
(\mathrm{n}=1) \text {; other }(\mathrm{n}=3)\end{array}$ & $\begin{array}{l}\text { Mixed-methods - } \\
\text { Qualitative } \\
\text { element individual } \\
\text { interviews }\end{array}$ & $\begin{array}{l}\text { Caregiving had an impact on carers' work, family } \\
\text { and health. Carers found managing paid employment } \\
\text { and caregiving work difficult; they experienced a loss } \\
\text { of intimacy and family conflicts resulting from the } \\
\text { demands of caregiving; and their health deteriorated } \\
\text { as a result of the physical and/or emotional demands } \\
\text { of caring for a person with multimorbidity. Even } \\
\text { though there were many challenges faced by carers, } \\
\text { they were able to find meaning in their caregiving }\end{array}$ \\
\hline
\end{tabular}




\begin{tabular}{|c|c|c|c|c|c|c|c|c|c|}
\hline & & & & & & $\begin{array}{l}76-80(\mathrm{n}=4) \\
81+(\mathrm{n}=5)\end{array}$ & & & $\begin{array}{l}\text { role, experiencing pride, increased empathy and } \\
\text { becoming closer to the care-recipient. }\end{array}$ \\
\hline & $* * *$ & Ellis et al. 2017 & US & $\begin{array}{l}\text { Cancer and comorbid } \\
\text { chronic conditions }\end{array}$ & 484 & $\begin{array}{l}\mathrm{M}=56.5 \text { years } \\
\text { (range 18-88) }\end{array}$ & $\begin{array}{l}\text { Reported as: Spouse } \\
(70 \%) \text {; daughter } \\
(12 \%) \text {; son }(3.3 \%) \text {; } \\
\text { sibling }(0.2 \%) \text {; other } \\
\text { relative }(5.6 \%) \text {; friend } \\
(4.3 \%) \text {; unknown } \\
(4.5 \%)\end{array}$ & $\begin{array}{l}\text { Quantitative } \\
\text { cross-sectional } \\
\text { questionnaires } \\
\text { (baseline time- } \\
\text { point from a RCT } \\
\text { with patient-carer } \\
\text { dyads) }\end{array}$ & $\begin{array}{l}\text { More patient comorbidities were associated with } \\
\text { lower meaning-based coping among caregivers. } \\
\text { More carer meaning-based coping was significantly } \\
\text { associated with higher carer quality of life. There } \\
\text { were significant indirect effects of patient number of } \\
\text { comorbidities on caregiver quality of life, caregivers' } \\
\text { own number of chronic conditions on caregiver } \\
\text { quality of life, and caregiver number of chronic } \\
\text { conditions on patient quality of life, all mediated by } \\
\text { caregiver meaning-based coping. }\end{array}$ \\
\hline [13] & $* *$ & $\begin{array}{l}\text { El-Mallakh et } \\
\text { al. } 2013\end{array}$ & US & $\begin{array}{l}\text { Schizophrenia and } \\
\text { diabetes }\end{array}$ & 28 & $\begin{array}{l}\mathrm{M}=50.4 \text { years } \\
\text { (range not } \\
\text { reported) }\end{array}$ & $\begin{array}{l}\text { Parent }(\mathrm{n}=8) \text {; adult } \\
\text { child }(\mathrm{n}=2) \text {; sibling } \\
(\mathrm{n}=5) \text {; friend }(\mathrm{n}=5) \text {; } \\
\text { spouse }(\mathrm{n}=3) \text {; other } \\
(\mathrm{n}=5)\end{array}$ & $\begin{array}{l}\text { Quantitative } \\
\text { cross-sectional } \\
\text { questionnaires }\end{array}$ & $\begin{array}{l}\text { Carers' knowledge of care-recipients' comorbid } \\
\text { diabetes was low, with the mean knowledge score } \\
\text { indicating that less than half of the items were } \\
\text { answered correctly. Items with the lowest scores } \\
\text { included knowledge about signs of ketoacidosis, } \\
\text { causes of an insulin reaction, and causes of } \\
\text { hypoglycaemia. Objective caregiver burden was } \\
\text { highest for providing assistance with daily living } \\
\text { activities. Subjective burden was highest for some } \\
\text { behaviour supervision activities including dealing } \\
\text { with threatening behaviour; and for non-adherence to } \\
\text { diabetes care. }\end{array}$ \\
\hline [14] & $* * *$ & $\begin{array}{l}\text { Espie et al. } \\
2003\end{array}$ & UK & $\begin{array}{l}\text { Intellectual disability } \\
\text { and epilepsy }\end{array}$ & 78 & $\begin{array}{l}\mathrm{M}=57 \text { years } \\
\text { (range not } \\
\text { reported) }\end{array}$ & Not reported & $\begin{array}{l}\text { Quantitative } \\
\text { cross-sectional } \\
\text { questionnaires }\end{array}$ & $\begin{array}{l}\text { Over half of the carer sample had 'higher than usual } \\
\text { stress', and one-third exhibited a clinically significan } \\
\text { level of anxiety symptoms. Stress was higher in } \\
\text { younger carers, and side effects from care-recipient's } \\
\text { medication contributed to carer stress. }\end{array}$ \\
\hline
\end{tabular}




\begin{tabular}{|c|c|c|c|c|c|c|c|c|c|}
\hline [15] & $* * *$ & $\begin{array}{l}\text { García- } \\
\text { Fernández et al. } \\
2014\end{array}$ & Spain & $\begin{array}{l}\text { Multiple chronic } \\
\text { conditions (any) }\end{array}$ & 255 & $\begin{array}{l}M=56.6 \text { years } \\
\text { (range not } \\
\text { reported) }\end{array}$ & $\begin{array}{l}\text { Reported as: Adult } \\
\text { child }(46.7 \%) \text {; spouse } \\
(35.7 \%) \text {; } \\
\text { son/daughter-in-law } \\
(6.7 \%) \text {; sibling } \\
(3.9 \%) \text {; parent }(3.5 \%) \text {; } \\
\text { other }(3.5 \%)\end{array}$ & $\begin{array}{l}\text { Quantitative } \\
\text { non-randomised } \\
\text { comparison of } \\
\text { nurse case } \\
\text { management with } \\
\text { standard care, } \\
\text { questionnaires } \\
\text { during patient's } \\
\text { hospital stay and } \\
90 \text { days post- } \\
\text { discharge }\end{array}$ & $\begin{array}{l}\text { Nurse case management prevented a post-discharge } \\
\text { increase in dependence of care-recipient, with level } \\
\text { of dependence of care-recipient remaining the same } \\
\text { in the nurse case managed cohort, but a loss of } \\
\text { autonomy of almost } 30 \% \text { in the control group. } \\
\text { However, there was no significant intergroup } \\
\text { differences in caregiver burden. }\end{array}$ \\
\hline [16] & $* *$ & Gill et al. 2014 & Canada & $\begin{array}{l}\text { Multiple chronic } \\
\text { conditions (any) }\end{array}$ & 28 & $\begin{array}{l}M=70.5 \text { years } \\
\text { (range } 50-91 \text { ) }\end{array}$ & $\begin{array}{l}\text { Spouse }(n=17) ; \text { adult } \\
\text { child }(n=9) ; \text { sibling } \\
(n=1) ; \text { friend }(n=1)\end{array}$ & $\begin{array}{l}\text { Qualitative } \\
\text { individual } \\
\text { interviews }\end{array}$ & $\begin{array}{l}\text { Carers experienced system-level challenges including } \\
\text { poor communication, a lack of care coordination, } \\
\text { specialist physicians not having up-to-date } \\
\text { information regarding care-recipient's health history } \\
\text { and long wait times; and patient-level challenges } \\
\text { including managing lack of adherence to treatment } \\
\text { regimens and facing challenging decisions regarding } \\
\text { care-recipient's treatment. }\end{array}$ \\
\hline [17] & $* * *$ & $\begin{array}{l}\text { Kuluski et al. } \\
2013\end{array}$ & Canada & $\begin{array}{l}\text { Multiple chronic } \\
\text { conditions (any) }\end{array}$ & 28 & $\begin{array}{l}M=70.5 \text { years } \\
\text { (range } 50-91 \text { ) }\end{array}$ & $\begin{array}{l}\text { Spouse }(n=17) ; \text { adult } \\
\text { child }(n=9) ; \text { sibling } \\
(n=1) ; \text { friend }(n=1)\end{array}$ & $\begin{array}{l}\text { Qualitative } \\
\text { individual } \\
\text { interviews }\end{array}$ & $\begin{array}{l}\text { Carers acknowledged their own levels of anxiety and } \\
\text { stress; expressed a need for getting more care } \\
\text { supports in place; but reported that care-recipients } \\
\text { were resistant to such care. }\end{array}$ \\
\hline [18] & $* * * *$ & $\begin{array}{l}\text { Giovannetti et } \\
\text { al. } 2011\end{array}$ & US & $\begin{array}{l}\text { Multiple chronic } \\
\text { conditions (any) }\end{array}$ & 308 & $\begin{array}{l}\mathrm{M}=61.72 \\
\text { years (range not } \\
\text { reported) }\end{array}$ & $\begin{array}{l}\text { Spouse }(n=142) \\
\text { adult child }(n=133) \text {; } \\
\text { other }(n=33)\end{array}$ & $\begin{array}{l}\text { Quantitative } \\
\text { cross-sectional } \\
\text { questionnaires } \\
\text { (baseline time- } \\
\text { point from a RCT } \\
\text { with patient-carer } \\
\text { dyads) }\end{array}$ & $\begin{array}{l}\text { Number of health care tasks performed was } \\
\text { significantly positively associated with increased } \\
\text { health care task difficulty (HCTD), and younger } \\
\text { caregiver age was associated with a decreased } \\
\text { likelihood of reporting a high versus low level of } \\
\text { HCTD. The carer-reported quality of relationship } \\
\text { with the care-recipient and carer self-efficacy were } \\
\text { significantly negatively associated with HCTD. }\end{array}$ \\
\hline
\end{tabular}




\begin{tabular}{|c|c|c|c|c|c|c|c|c|c|}
\hline [19] & $* * * * *$ & $\begin{array}{l}\text { Giovannetti et } \\
\text { al. } 2013\end{array}$ & US & $\begin{array}{l}\text { Multiple chronic } \\
\text { conditions (any) }\end{array}$ & 247 & $\begin{array}{l}\text { Reported as: } \\
60+(\mathrm{n}=137) ; \\
<60(\mathrm{n}=110)\end{array}$ & $\begin{array}{l}\text { Spouse }(\mathrm{n}=126) \text {; } \\
\text { adult child }(\mathrm{n}=96) \text {; } \\
\text { other }(\mathrm{n}=25)\end{array}$ & $\begin{array}{l}\text { Quantitative } \\
\text { cross-sectional } \\
\text { questionnaires } \\
\text { (baseline time- } \\
\text { point from a RCT } \\
\text { with patient-carer } \\
\text { dyads) }\end{array}$ & $\begin{array}{l}\text { Agreement about the quality of chronic illness care } \\
\text { between carers and care-recipients was low. Carers } \\
\text { who reported greater difficulty assisting care- } \\
\text { recipients, and care-recipients taking ten or more } \\
\text { medications daily had less agreement about the } \\
\text { quality of care provided. }\end{array}$ \\
\hline [20] & $* * *$ & $\begin{array}{l}\text { Wolff et al. } \\
2009\end{array}$ & US & $\begin{array}{l}\text { Multiple chronic } \\
\text { conditions (any) }\end{array}$ & 308 & $\begin{array}{l}\mathrm{M}=61.8 \text { years } \\
\text { (range not } \\
\text { reported) }\end{array}$ & $\begin{array}{l}\text { Reported as: Spouse } \\
(46.1 \%) \text {; adult child } \\
(44.5 \%)\end{array}$ & $\begin{array}{l}\text { Quantitative } \\
\text { cluster RCT of } \\
\text { patient-carer } \\
\text { dyads comparing } \\
\text { The Guided Care } \\
\text { Program for } \\
\text { Families and } \\
\text { Friends (GCPFF) } \\
\text { with standard } \\
\text { care, } \\
\text { questionnaires at } \\
\text { baseline and 6- } \\
\text { month follow-up }\end{array}$ & $\begin{array}{l}\text { At 6-month follow-up, intervention group carers' } \\
\text { mean depression and caregiver strain scores were } \\
\text { lower than control group carers', though not } \\
\text { significant. Among carers who provided more than } \\
14 \text { hours of weekly assistance, intervention group } \\
\text { carers' mean caregiver strain scores were } \\
\text { significantly lower than the control group. }\end{array}$ \\
\hline [21] & $* * *$ & $\begin{array}{l}\text { Wolff et al. } \\
2010\end{array}$ & US & $\begin{array}{l}\text { Multiple chronic } \\
\text { conditions (any) }\end{array}$ & 196 & $\begin{array}{l}\mathrm{M}=61.3 \text { years } \\
\text { (range not } \\
\text { reported) }\end{array}$ & $\begin{array}{l}\text { Reported as: Spouse } \\
(47.9 \%) \text {; adult child } \\
(43.9 \%)\end{array}$ & $\begin{array}{l}\text { Quantitative } \\
\text { cluster RCT of } \\
\text { patient-carer } \\
\text { dyads comparing } \\
\text { The GCPFF with } \\
\text { standard care, } \\
\text { questionnaires at } \\
\text { baseline and 18- } \\
\text { month follow-up }\end{array}$ & $\begin{array}{l}\text { At 18-month follow-up, intervention group carers } \\
\text { reported the overall quality of their care-recipients, } \\
\text { care to be significantly higher. However, GCPFF did } \\
\text { not improve carers' depressive symptoms, strain, or } \\
\text { productivity. Elements of the GCPFF were poorly } \\
\text { attended by carers due to competing demands, } \\
\text { inconvenient location or time and lack of interest. }\end{array}$ \\
\hline
\end{tabular}




\begin{tabular}{|c|c|c|c|c|c|c|c|c|c|}
\hline [22] & $* * *$ & $\begin{array}{l}\text { Gonzáles- } \\
\text { Ortega et al. } \\
2016\end{array}$ & Spain & $\begin{array}{l}\text { Multiple chronic } \\
\text { conditions (any) }\end{array}$ & 28 & Not reported & Not reported & $\begin{array}{l}\text { Quantitative } \\
\text { RCT of patient- } \\
\text { carer dyads } \\
\text { comparing } \\
\text { telephone } \\
\text { coaching with } \\
\text { standard care, } \\
\text { questionnaires at } \\
\text { baseline and 6- } \\
\text { month follow-up }\end{array}$ & $\begin{array}{l}13.2 \% \text { of the informal carers interviewed displayed } \\
\text { caregiver overburden. Despite being a secondary } \\
\text { endpoint of the study, changes in caregiver } \\
\text { overburden were not measured due to insufficient } \\
\text { data to draw any conclusions as only } 28 \text { carers could } \\
\text { be reached to carry out the Zarit caregiver burden } \\
\text { test. }\end{array}$ \\
\hline [23] & $* * * *$ & $\begin{array}{l}\text { Hjelm et al. } \\
2015\end{array}$ & Sweden & $\begin{array}{l}\text { Multiple chronic } \\
\text { conditions (any) }\end{array}$ & 16 & $\begin{array}{l}\mathrm{M}=63 \text { years } \\
\text { (range 38-89) }\end{array}$ & $\begin{array}{l}\text { Spouse }(n=5) \text {; adult } \\
\text { child }(n=10) \text {; sibling } \\
(n=1)\end{array}$ & $\begin{array}{l}\text { Qualitative } \\
\text { individual } \\
\text { interviews }\end{array}$ & $\begin{array}{l}\text { Contact with case managers contributed to a sense of } \\
\text { security among carers; carers felt that case managers } \\
\text { understood them, appreciated their caregiving efforts, } \\
\text { and improved their sense of feeling alone; carers } \\
\text { described case managers as their guide to navigate } \\
\text { them through the health system, expressing that they } \\
\text { benefitted from their professional knowledge, } \\
\text { resulting in increased carer competence. }\end{array}$ \\
\hline [24] & $* * *$ & $\begin{array}{l}\text { Jowsey et al. } \\
2009\end{array}$ & UK & $\begin{array}{l}\text { Dementia and serious } \\
\text { visual impairment }\end{array}$ & 14 & Not reported & Not reported & $\begin{array}{l}\text { Qualitative } \\
\text { individual } \\
\text { interviews }\end{array}$ & $\begin{array}{l}\text { Comorbidity increased amount of time spent } \\
\text { managing health and increased care-recipient } \\
\text { dependency on others. Comorbidity influenced carer } \\
\text { and care-recipient capacity to manage chronic illness } \\
\text { in three ways: } 1 \text { ) comorbidity created barriers to } \\
\text { acting on risk factors; } 2 \text { ) it complicated the process of } \\
\text { recognising the early symptoms of deterioration of } \\
\text { each condition. Carers reported being uncertain of } \\
\text { the cause of care-recipient symptoms and } 3 \text { ) it } \\
\text { complicated capacity to manage medication. Many } \\
\text { care-recipients were prescribed multiple mediations } \\
\text { that they struggled to manage, and carers reported } \\
\text { assuming this role. * }\end{array}$ \\
\hline
\end{tabular}




\begin{tabular}{|c|c|c|c|c|c|c|c|}
\hline$[25] \quad * * *$ & $\begin{array}{l}\text { Lawrence et al. } \\
2009\end{array}$ & UK & $\begin{array}{l}\text { Dementia and serious } \\
\text { visual impairment }\end{array}$ & 17 & Not reported & $\begin{array}{l}\text { Spouse }(\mathrm{n}=3) \text {; adult } \\
\text { child }(\mathrm{n}=10) ; \\
\text { son/daughter-in-law ( } \mathrm{n} \\
=1) \text {; sibling }(\mathrm{n}=1) ; \\
\text { other relative }(\mathrm{n}=1) ; \\
\text { friend }(\mathrm{n}=1)\end{array}$ & $\begin{array}{l}\text { Qualitativ } \\
\text { individual } \\
\text { interviews }\end{array}$ \\
\hline
\end{tabular}

\begin{tabular}{|c|c|c|c|c|c|c|c|c|c|}
\hline [26] & $* * * *$ & $\begin{array}{l}\text { Lebrec et al. } \\
2016\end{array}$ & $\begin{array}{l}\text { UK, } \\
\text { France } \\
\& \\
\text { Germany }\end{array}$ & $\begin{array}{l}\text { Diabetes and } \\
\text { Alzheimer's disease }\end{array}$ & 188 & $\begin{array}{l}\mathrm{M}=65 \text { years } \\
\text { (range not } \\
\text { reported) }\end{array}$ & $\begin{array}{l}\text { Spouse }(\mathrm{n}=109) \text {; } \\
\text { adult child }(\mathrm{n}=69) \text {; } \\
\text { friend }(\mathrm{n}=2) \text {; other }(\mathrm{n} \\
=8)\end{array}$ & $\begin{array}{l}\text { Quantitative } \\
\text { cross-sectional } \\
\text { questionnaires } \\
\text { (baseline data } \\
\text { from the GERAS } \\
\text { prospective } \\
\text { observational } \\
\text { study) }\end{array}$ & $\begin{array}{l}\text { Carers of people with diabetes and Alzheimer's } \\
\text { disease spent significantly more time on instrumental } \\
\text { activities of daily living than carers of those with } \\
\text { Alzheimer's disease alone. Care-recipients with } \\
\text { diabetes and Alzheimer's disease had a } 63 \% \text { increase } \\
\text { in the odds of requiring supervision compared to } \\
\text { those with just Alzheimer's disease. }\end{array}$ \\
\hline [27] & $* *$ & Lee et al. 2016 & Singapore & $\begin{array}{l}\text { Diabetes and end } \\
\text { stage renal disease }\end{array}$ & 20 & $\begin{array}{l}\mathrm{M}=54.2 \text { years } \\
\text { (range not } \\
\text { reported) }\end{array}$ & $\begin{array}{l}\text { Spouse }(\mathrm{n}=14) \text {; adult } \\
\text { child }(\mathrm{n}=5) \text {; parent ( } \\
=1)\end{array}$ & $\begin{array}{l}\text { Qualitative } \\
\text { individual } \\
\text { interviews }\end{array}$ & $\begin{array}{l}\text { Carers experienced challenges of caregiving, } \\
\text { including managing care-recipients' diet, emotional } \\
\text { outbursts and mobility dependence on carer. Carers } \\
\text { reported how challenges were met with limited } \\
\text { resources, including poor knowledge and lack of } \\
\text { confidence in ability to implement care guidelines; } \\
\text { financial constraints of non-publicly funded } \\
\text { healthcare and other expenses such as transportation } \\
\text { and incontinence products; and a lack of social } \\
\text { support. Caregiving had an adverse impact on cares' }\end{array}$ \\
\hline
\end{tabular}

Increased emotional dependency of care-recipients enhanced the burden on carers, who felt responsible for stimulating and entertaining the care-recipient.

Many carers were physically exhausted but found it difficult to leave care-recipients. Carers were concerned about care-recipient safety, prompting them to limit care-recipients' activities, which led to conflict. Carers had to manage care-recipient symptoms such as visual hallucinations, disorientation and distress which could be manifested in agitated or aggressive behaviour. Carers were uncertain about how best to deal with hallucinations. 


\begin{tabular}{|c|c|c|c|c|c|c|c|c|c|}
\hline & & & & & & & & & $\begin{array}{l}\text { physical and psychological wellbeing, and their } \\
\text { employment. }\end{array}$ \\
\hline [28] & $* * * *$ & Lo et al. 2016 & Australia & $\begin{array}{l}\text { Diabetes and chronic } \\
\text { kidney disease (CKD) }\end{array}$ & 8 & Not reported & Not reported & $\begin{array}{l}\text { Qualitative } \\
\text { individual } \\
\text { interviews }\end{array}$ & $\begin{array}{l}\text { Identified patient level and health service level } \\
\text { factors that influenced health care for comorbid } \\
\text { diabetes and CKD. Patient level factors included: } \\
\text { patient self-management; socio-economic situation; } \\
\text { and adverse experiences related to comorbid diabetes } \\
\text { and CKD and its treatment. Health service level } \\
\text { factors included: prevention and awareness of } \\
\text { comorbid diabetes and CKD; patient and carer } \\
\text { empowerment to self-manage; poor coordination and } \\
\text { continuity of care; and poor recognition of } \\
\text { psychological comorbidity. * }\end{array}$ \\
\hline [29] & $* * *$ & $\begin{array}{l}\text { Mason et al. } \\
2016\end{array}$ & UK & $\begin{array}{l}\text { Multiple chronic } \\
\text { conditions (any) }\end{array}$ & 17 & Not reported & Not reported & $\begin{array}{l}\text { Qualitative } \\
\text { interviews (mix of } \\
\text { individual and } \\
\text { patient-carer } \\
\text { dyadic) }\end{array}$ & $\begin{array}{l}\text { Two overarching themes were identified: 1) } \\
\text { Experiences of care, where carers and care-recipients } \\
\text { struggled with multiple changing medications, } \\
\text { multiple single illness-focused services, and a lack of } \\
\text { coordination and continuity of care; and 2) } \\
\text { Understanding of deteriorating health due to multiple } \\
\text { conditions, where carers and care-recipients saw } \\
\text { deteriorating health as part of 'growing old', and } \\
\text { used a 'day-to-day' approach to care management } \\
\text { that hindered engagement with advance care } \\
\text { planning and discussions about future care. * }\end{array}$ \\
\hline [30] & $* * * *$ & $\begin{array}{l}\text { Matthews et al. } \\
2008\end{array}$ & UK & $\begin{array}{l}\text { Intellectual disability } \\
\text { and epilepsy }\end{array}$ & 318 & Not reported & Not reported & $\begin{array}{l}\text { Quantitative } \\
\text { cross-sectional } \\
\text { questionnaires }\end{array}$ & $\begin{array}{l}\text { Carers who reported that comorbid epilepsy had an } \\
\text { impact on care-recipient's lifestyle had significantly } \\
\text { higher epilepsy concerns. Higher concerns were } \\
\text { related to seizure frequency and a history of injury. } \\
\text { There were no significant differences in carer malaise } \\
\text { or strain between those with intellectual disability } \\
\text { and epilepsy and those with intellectual disability } \\
\text { alone. }\end{array}$ \\
\hline
\end{tabular}




\begin{tabular}{|c|c|c|c|c|c|c|c|c|c|}
\hline [31] & $* *$ & $\begin{array}{l}\text { Mengoni et al. } \\
2016\end{array}$ & UK & $\begin{array}{l}\text { Intellectual disability } \\
\text { and epilepsy }\end{array}$ & 6 & Not reported & Not reported & $\begin{array}{l}\text { Qualitative } \\
\text { interviews (mix of } \\
\text { individual and } \\
\text { patient-carer } \\
\text { dyadic) }\end{array}$ & $\begin{array}{l}\text { Three overarching themes were identified in } \\
\text { experiences of epilepsy management in people with } \\
\text { intellectual disabilities. 1) Participant characteristics, } \\
\text { such as diversity regarding health profiles, perceived } \\
\text { control of epilepsy and support needs, 2) Living with } \\
\text { epilepsy, such as the lifelong impact of epilepsy on } \\
\text { quality of life; and 3) Epilepsy management and } \\
\text { information needs, including the perceived burden of } \\
\text { epilepsy and difficulty managing the condition and } \\
\text { an overall lack of written accessible information } \\
\text { about epilepsy. * }\end{array}$ \\
\hline [32] & $* * * *$ & $\begin{array}{l}\text { Morales- } \\
\text { Asencio et al. } \\
2016\end{array}$ & Spain & $\begin{array}{l}\text { Multiple chronic } \\
\text { conditions (any) }\end{array}$ & 16 & Not reported & $\begin{array}{l}\text { Spouse }(\mathrm{n}=13) ; \text { adult } \\
\text { child }(\mathrm{n}=3)\end{array}$ & $\begin{array}{l}\text { Qualitative } \\
\text { dyadic interviews } \\
\text { (patient-carer } \\
\text { dyads) }\end{array}$ & $\begin{array}{l}\text { Key themes identified in relation to health care } \\
\text { services included: 1) Three phases of the disease } \\
\text { experience: the onset and initial adaptation, the } \\
\text { impact on quality of life, and the final stage governed } \\
\text { by condition complexity; 2) Adaptation to long-term } \\
\text { disease involving coping mechanisms such as } \\
\text { information seeking and family support; } 3 \text { ) Self-care } \\
\text { information, health care providers were not very } \\
\text { proactive as regards the early promotion of measures } \\
\text { for self-care, one alternative information source used } \\
\text { was the internet; and 4) Fragmented care and lack of } \\
\text { coordination of services. * }\end{array}$ \\
\hline [33] & $* * *$ & $\begin{array}{l}\text { Nicholas et al. } \\
2017\end{array}$ & Canada & $\begin{array}{l}\text { Developmental } \\
\text { disability and mental } \\
\text { illness }\end{array}$ & 8 & Not reported & Parent $(\mathrm{n}=8)$ & $\begin{array}{l}\text { Qualitative } \\
\text { individual } \\
\text { interviews }\end{array}$ & $\begin{array}{l}\text { Four themes were identified: 1) The need for carers } \\
\text { to provide complex care amid gaps in an } \\
\text { uncoordinated system; 2) Difficulties exacerbated by } \\
\text { insufficient funding and housing; 3) Carer support } \\
\text { depended upon yet carers often excluded from formal } \\
\text { care planning; and 4) Supportive care, where despite } \\
\text { the multiple negative experiences, participants } \\
\text { described instances of positive interactions with care } \\
\text { providers. * }\end{array}$ \\
\hline
\end{tabular}




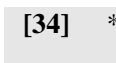

$\begin{array}{lll}\text { Ploeg et al. } & \text { Canada } & \begin{array}{l}\text { Multiple chronic } \\ \text { conditions (any) }\end{array} \\ 2017 & & \end{array}$

Multiple chronic
conditions (any)

47

$\begin{array}{lll}\text { Reported as: } & \text { Spouse }(\mathrm{n}=32) ; & \text { Qualitative } \\ 18-44(\mathrm{n}=4) ; & \text { parent }(\mathrm{n}=13) ; & \text { individual } \\ 45-64(\mathrm{n}=14) ; & \text { mother-in-law }(\mathrm{n}=1) ; & \text { interviews } \\ 65-74(\mathrm{n}=17) ; & \text { grandfather }(\mathrm{n}=1) & \\ 75+(\mathrm{n}=12) & & \end{array}$

described as: 1) overwhelming, draining and

complicated; 2) organising pills and appointments; 3)

being split into pieces; 4) doing what the doctor says;

5) relying on family and friends; and 6) having

difficulty getting outside helped. Carers were heavily

relied on to support care in the home. *

${ }^{1}$ Quality rating from $1 *$ to $4 *$ using the Mixed Methods Appraisal Tool (MMAT)

${ }^{2}$ Study design refers to those aspects involving caregivers (i.e. there are other aspects to the design of some studies involving patient and/or health care professional participants) and those aspects relevant to the data currently reported (i.e. some studies report a subset of data from a larger study).

* Refers to qualitative papers which also included care-recipient and/or health professional participants and the themes were derived from analysis of all interviews together (i.e. data from carers were analysed together with care-recipient and/or health professional data) 
Appendix 1: Search strategy

\begin{tabular}{|c|c|}
\hline No. & Combination of search terms \\
\hline 1 & multimorbid* AND caregiver* \\
\hline 2 & multimorbid* AND carer* \\
\hline 3 & comorbid* AND caregiver* \\
\hline 4 & comorbid* AND carer* \\
\hline 5 & "multiple morbidit*" AND carer* \\
\hline 6 & "multiple morbidit*" AND caregiver* \\
\hline 7 & multi-morbid* AND caregiver* \\
\hline 8 & multi-morbid* AND carer* \\
\hline 9 & co-morbid* AND caregiver* \\
\hline 10 & co-morbid* AND carer* \\
\hline 11 & "more than one illness" AND carer* \\
\hline 12 & "more than one disease" AND carer* \\
\hline 13 & "more than one condition" AND carer* \\
\hline 14 & "more than one illness" AND caregiver* \\
\hline 15 & "more than one disease" AND caregiver* \\
\hline 16 & "more than one condition" AND caregiver* \\
\hline 17 & "multiple illnesses" AND carer* \\
\hline 18 & "multiple illnesses" AND caregiver* \\
\hline 19 & "multiple conditions" AND carer* \\
\hline 20 & "multiple conditions" AND caregiver* \\
\hline 21 & "multiple diseases" AND carer* \\
\hline 22 & "multiple diseases" AND caregiver* \\
\hline 23 & multimorbid* AND spouse \\
\hline 24 & comorbid* AND spouse \\
\hline 25 & multi-morbid* AND spouse \\
\hline 26 & co-morbid* AND spouse \\
\hline 27 & "guided care" AND caregiver* \\
\hline 28 & "guided care" AND carer* \\
\hline 29 & "concomitant disease" ${ }^{*}$ AND carer* \\
\hline 30 & "concomitant disease*" AND caregiver* \\
\hline 31 & "concomitant illness*" AND carer* \\
\hline 32 & "concomitant illness*" AND caregiver* \\
\hline 33 & "concomitant condition*" AND carer* \\
\hline 34 & "concomitant condition*" AND caregiver* \\
\hline 35 & "dual disorder*" AND carer* \\
\hline 36 & "dual disorder*" AND caregiver* \\
\hline 37 & "dual diagnosis" AND carer* \\
\hline 38 & "dual diagnosis" AND caregiver* \\
\hline 39 & "multiple pathologies" AND carer* \\
\hline 40 & "multiple pathologies" AND caregiver* \\
\hline 41 & "complex chronic disease" AND carer* \\
\hline 42 & "complex chronic disease" AND caregiver* \\
\hline 43 & "multiple morbidity" AND carer* \\
\hline 44 & "multiple morbidity" AND caregiver* \\
\hline
\end{tabular}

